\title{
2003 Annual Report
}

SUBLETTE MULE DEER STUDY (PHASE II): Long-term monitoring plan to assess potential impacts of energy development on mule deer in the Pinedale Anticline Project Area.

Prepared for:

Questar Exploration and Production Company

Independence Plaza

$105017^{\text {th }}$ St., Suite 500

Denver, CO 80265

TRC Mariah Associates, Inc. 605 Skyline Road

Laramie, WY 82070

Bureau of Land Management

Pinedale Field Office 432 E. Mill Street PO Box 768

Pinedale, WY 82941

Wyoming Game and Fish Department

Pinedale Regional Office PO Box 850

Pinedale, WY 82941

Prepared by:

Hall Sawyer Ryan Neilson Dale Strickland

Western EcoSystems Technology, Inc. 2003 Central Avenue

Cheyenne, WY 82001 


\section{ACKNOWLEDGEMENTS}

Phase II of the Sublette Mule Deer Study has been a cooperative effort among agencies, industry, and private organizations. This project was largely funded by Questar Exploration and Production Company (QEP). The Pinedale Field Office of the Bureau of Land Management (BLM) and the Wildlife Heritage Foundation of Wyoming (WHFW) provided additional funding. The Jackson/Pinedale Region of the Wyoming Game and Fish Department (WGFD) provided logistical support, project assistance, and was responsible for portions of the data collection. Many thanks to Ron Hogan (QEP), Jane Seiler (QEP), Keith Andrews (BLM), Karen Rogers (BLM), Pete Guernsey (TRC), Scott Smith (WGFD), Herb Haley (WGFD), Bernie Holz (WGFD), Scott Edberg (WGFD), Scott Werbelow (WGFD), Dan Stroud (WGFD), Dean Clause (WGFD), Fred Lindzey (UW), Hawkins \& Powers Aviation, and Gary Lust (Mountain Air). Thanks to John Amos and SkyTruth for satellite imagery and image processing.

\section{TABLE OF CONTENTS}

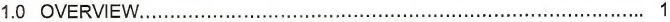

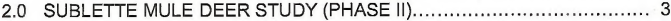

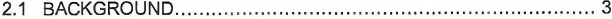

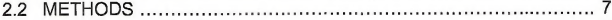

2.2.1 Deer Capture................................................... 7

2.2.2 Winter Movement and Distribution Patterns..................... 7

2.2.3 Population Characteristics...................................... 7

2.2.3.1 Abundance and Density Estimates..................... 7

2.2.3.2 Reproduction............................................ 8

2.2.3.3 Over-winter fawn survival............................. 8

2.2.3.4 Adult winter survival..................................... 8

2.2 .4 Resource Selection................................................ 8

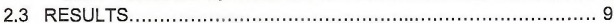

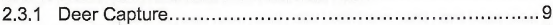

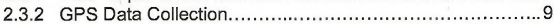

2.3.3 Winter Movement and Distribution Patterns..................... 10

2.3.4 Population Characteristics....................................... 18

2.3.4.1 Abundance and Density Estimates.................... 18

2.3.4.2 Reproduction............................................ 19

2.3.4.3 Over-winter fawn survival.............................. 20

2.3.4.4 Adult winter survival.................................... 21

2.3.4.5 Wyoming Game and Fish Department Job

Completion Report................................... 21

2.3.5 Resource Selection.............................................. 21

2.4 DISCUSSION AND FUTURE DIRECTION ............................ 22

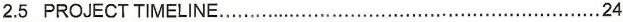

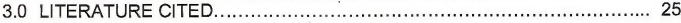

APPENDIX A: Equations Used to Calculate Abundance and Density Estimates.............................................................. 27

APPENDIX B: Wyoming Game and Fish Department Job Completion Report

For the Sublette Mule Deer DAU, 2002 .............................. 28 


\section{LIST OF TABLES}

Table 2.1 Summary statistics for abundance and density estimates in

Table 2.2 Mule deer population characteristics measured for treatment and control areas by Wyoming Game and Fish Department, 1992-2003.

Table 2.3 Mule deer count data and calculations for over-winter fawn survival in the control (PFWRC), 1999-2003.

Table 2.4 Mule deer count data and calculations for over-winter fawn survival in the treatment (MWRC), 1999-2003.

Table 2.5 Winter survival rates and summary statistics for adult female deer in treatment and control areas.

\section{LIST OF FIGURES}

Figure 1.1 Location of Pinedale Anticline Project Area in western Wyoming

(Fig.1 from BLM 2000).

Figure 2.1 Location of the Sublette Mule Deer Data Analysis Unit, Wyoming Game and Fish Department Hunt Areas, and the Mesa and Pinedale Front Winter Range Complexes

Figure 2.2 GPS locations of deer \#861 in the Pinedale Anticline Project Area (PAPA), December 20, 2002 - April 15, 2003.

Figure 2.3 GPS locations of deer \#862 in the Pinedale Anticline Project Area (PAPA), December 20, 2002 - April 15, 2003.

Figure 2.4 GPS locations of deer \#866 in the Pinedale Anticline Project Area (PAPA), December 20, 2002 - April 15, 2003.

Figure 2.5 GPS locations of deer \#867b in the Pinedale Anticline Project Area (PAPA), December 20, 2002 - April 15, 2003.

Figure 2.6 GPS locations of deer \#868 in the Pinedale Anticline Project Area (PAPA), December 20, 2002 - April 15, 2003.

Figure 2.7 GPS locations of deer \#869 in the Pinedale Anticline Project Area (PAPA), December 20, 2002 - April 15, 2003.

Figure 2.8 GPS locations of deer \#867b in the Pinedale Anticline Project Area (PAPA), December 20, 2001 - April 15, 2002 (yellow) and December 20, 2002 - April 15, 2003 (blue). 
LIST OF FIGURES (continued)

Figure 2.9 GPS locations of deer \#868 in the Pinedale Anticline Project Area (PAPA), December 20, 2001 - April 15, 2002 (yellow) and December 20, 2002 - April 15, 2003 (blue).

Figure 2.10 GPS locations of all deer $(n=6)$ and land ownership of the Pinedale Anticline Project Area (PAPA), December 20, 2002 April 15, 2003.

Figure 2.11 GPS locations ( $n=7,190)$ of six deer captured in the control area along the Pinedale Front, December 20, 2002 - April 15, 2003

Figure 2.12 Location of sampling frames and $1-\mathrm{mi}^{2}$ quadrats used to calculate abundance and density estimates for control and treatment areas. 19

Figure 2.13 Fawn:doe ratios for treatment and control areas, 1999-2003...... 20

Figure 2.14 Estimated over-winter fawn survival in treatment and control areas, 1999-2003.

\section{LIST OF ACRONYMS}

$\begin{array}{ll}\text { BACl } & \text { Before-After Control-Impact } \\ \text { BLM } & \text { Bureau of Land Management } \\ \text { DAU } & \text { Data Analysis Unit } \\ \text { EIS } & \text { Environmental Impact Statement } \\ \text { GIS } & \text { Geographic Information System } \\ \text { GPS } & \text { Global Positioning System } \\ \text { HA } & \text { Hunt Area } \\ \text { JCR } & \text { Job Completion Report } \\ \text { MWRC } & \text { Mesa Winter Range Complex } \\ \text { NEPA } & \text { National Environmental Policy Act } \\ \text { NGO } & \text { Non-Government Organization } \\ \text { PAPA } & \text { Pinedale Anticline Project Area } \\ \text { PFWRC } & \text { Pinedale Front Winter Range Complex } \\ \text { QEP } & \text { Questar Exploration and Production Company } \\ \text { ROD } & \text { Record of Decision } \\ \text { TPB } & \text { Trapper's Point Bottleneck } \\ \text { TRC } & \text { TRC Mariah Associates, Inc. } \\ \text { UW } & \text { University of Wyoming } \\ \text { VHF } & \text { Very High Frequency } \\ \text { WGFD } & \text { Wyoming Game and Fish Department } \\ \text { WHFW } & \text { Wildlife Heritage Foundation of Wyoming }\end{array}$




\subsection{OVERVIEW}

In 1998 the Wyoming Cooperative Fish and Wildlife Research Unit began a collaborative study with industry, agencies, and private organizations to examine movement patterns and population characteristics of the Sublette mule deer (Odocoileus hemionus) herd in western Wyoming (Sawyer and Lindzey 2001). Although a variety of agencies and non-government organizations (NGOs) contributed to the study, it was funded largely by industry (Ultra Petroleum). Concurrently, the Bureau of Land Management (BLM), in compliance with the National Environmental Policy Act (NEPA), initiated an Environmental Impact Statement (EIS) to assess natural gas development in the 300-mi ${ }^{2}$ Pinedale Anticline Project Area (PAPA) (BLM 2000). The PAPA is located in west-central Wyoming in Sublette County, near the town of Pinedale (Figure 1.1). The PAPA is characterized by sagebrush communities and riparian habitats associated with the Green and New Fork Rivers. Elevations range from 6,800 to $7,800 \mathrm{ft}$. The PAPA consists primarily of federal lands $(80 \%)$ and minerals $(83 \%)$ administered by the BLM. The state of Wyoming owns $5 \%\left(15.2 \mathrm{mi}^{2}\right)$ of the surface and another $15 \%$ $\left(46.7 \mathrm{mi}^{2}\right)$ is private. Aside from the abundant energy resources, the PAPA is an important area for agriculture and provides winter range for 4,000-6,000 mule deer, 2,000-3,000 pronghorn (Antilocapra americana), and 3,000-4,000 sage grouse (Centrocercus urophasianus). While the project area is fairly large, most deer occur in the northern portion of the PAPA, an area locally known as "The Mesa", which includes approximately $100-\mathrm{mi}^{2}$.

The Sublette Mule Deer Study was originally designed to have two phases. The first phase of the study was intended to gather information needed by agencies to improve management of the Sublette deer herd, including the identification of important seasonal ranges, determination of migration routes, and estimation of survival rates (Sawyer and Lindzey 2001). Additionally, these data were collected so that pre-development information on the mule deer population would be available if Phase II of the study materialized. Phase II was envisioned as a long-term study that would examine the potential impacts of energy development on mule deer, using treatment and control areas, with energy development as the treatment.

Phase I was completed in March of 2001 (Sawyer and Lindzey 2001) and, following a 1-year pilot study (Sawyer et al. 2002), Phase II was initiated in December of 2002. Phase II is intended to be a long-term (= 5 years) study that examines the potential impacts of oil and gas development on the PAPA mule deer population. Phase II proposes a Before-After/Control-Impact (BACl) (Green 1979, Morrison et al. 2001) study design that uses the PAPA as a treatment area and a portion of the Pinedale Front as the control area. Mule deer population characteristics (survival, reproduction, density) and habitat use in relation to development features will be measured in both areas, and over time, performance of mule deer in the PAPA will be compared to those in the control area. This report summarizes the results from the 2003 study period. 


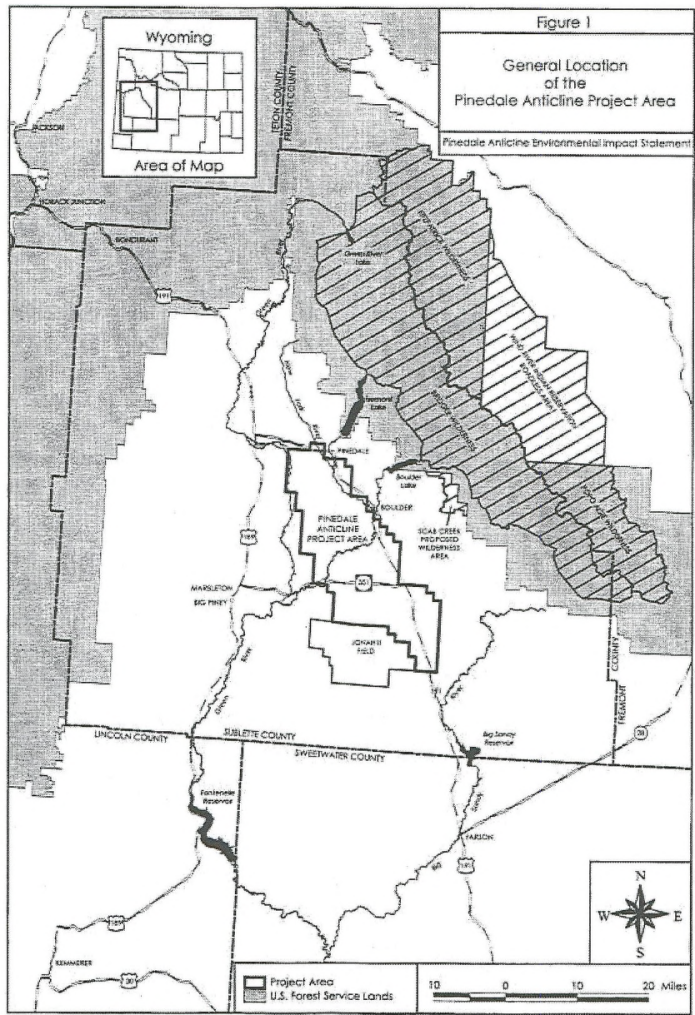

Figure 1.1 Location of Pinedale Anticline Project Area in western Wyoming (Fig. 1 from BLM 2000). 


\subsection{SUBLETTE MULE DEER STUDY}

\subsection{BACKGROUND}

Western Wyoming is home to the largest, most diverse ungulate populations in the Rocky Mountain region. Maintenance of these populations and protection of their habitats are primary concerns among public and private sectors. Because of their large numbers and economic importance, mule deer continue to be a top priority for the Wyoming Game and Fish Department (WGFD). The Sublette mule deer data analysis unit (DAU) includes 15 hunt areas (HA) (130, 138-142, 146, 150-156, and 162) (Figure 2.1) and has a post-season population objective of 32,000 (WGFD 2000). Study results from Phase I indicated that deer from the Sublette DAU seasonally migrate 60-100 miles to summer in portions of the Salt River Range, Wyoming Range, Wind River Range, Gros Ventre Range, and Snake River Range. During both spring and fall migrations, deer spent lengthy periods of time, often 4-5 months out of the year, on mid-elevation transition ranges that connect summer and wintering areas. Deer annually converged in the Green River Basin to winter one of two major wintering complexes; the Mesa Winter Range Complex (MWRC) and the Pinedale Front Winter Range Complex (PFWRC) (Figure 2.1). Generally, the MWRC includes the PAPA and those areas west of US 191, while the PFWRC includes those areas east of US 191 to the base of the Wind River Mountains.

Population parameters measured during the 3-year study (1998-2000) suggested the Sublette deer herd was performing well. Annual survival rates of radio-collared adult females $(n=149)$ averaged $85 \%$ and were consistent with populations studied in other western states (Unsworth et al. 1999). Fawn:doe ratios, an indicator of reproductive success, were among the highest in the state, averaging $>75$ fawns per 100 does for the study period and approximately 70 fawns per 100 does over the last decade (WGFD 2000). While the Sublette deer herd has been very productive in the past and knowledge of seasonal movements, migration routes, and survival rates has improved management, this deer herd is similar to others in that habitat loss, urban expansion, disease, and changes in vegetation continue to create major management concerns. Extensive energy development in the Green River Basin is thought to pose one of the most serious threats to mule deer populations in the region.

Natural gas production in Wyoming has steadily increased since the mid-1980's, particularly in the five counties that form the southwest quarter of the state: Sublette, Fremont, Lincoln, Uinta, and Sweetwater. This area of the state contains some of the largest and most productive gas fields in the nation, including the Jonah, Continental Divide/Wamsutter, Fontenelle, Big Piney-LaBarge, Moxa Arch, Riley Ridge, and the Pinedale Anticline. While coalbed methane development in the Powder River Basin has received much attention as of late, Sublette County continues to produce approximately 2.5 times more gas than Campbell County. Sublette County is the state's largest producer and accounts for $>30 \%$ of all Wyoming gas production (BLM 2002). Because of renewed political and economic support for developing domestic energy reserves, natural gas exploration, development, and production are at an all time high in Wyoming and expected only to increase. In July of 2000, the BLM approved the development of 700 producing well pads in the PAPA and recognized that this may require as many as 900 well pads to be constructed and drilled (BLM 2000). Additionally, 401 miles of pipeline and 276 miles of access roads were approved for development. 
-

-

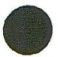




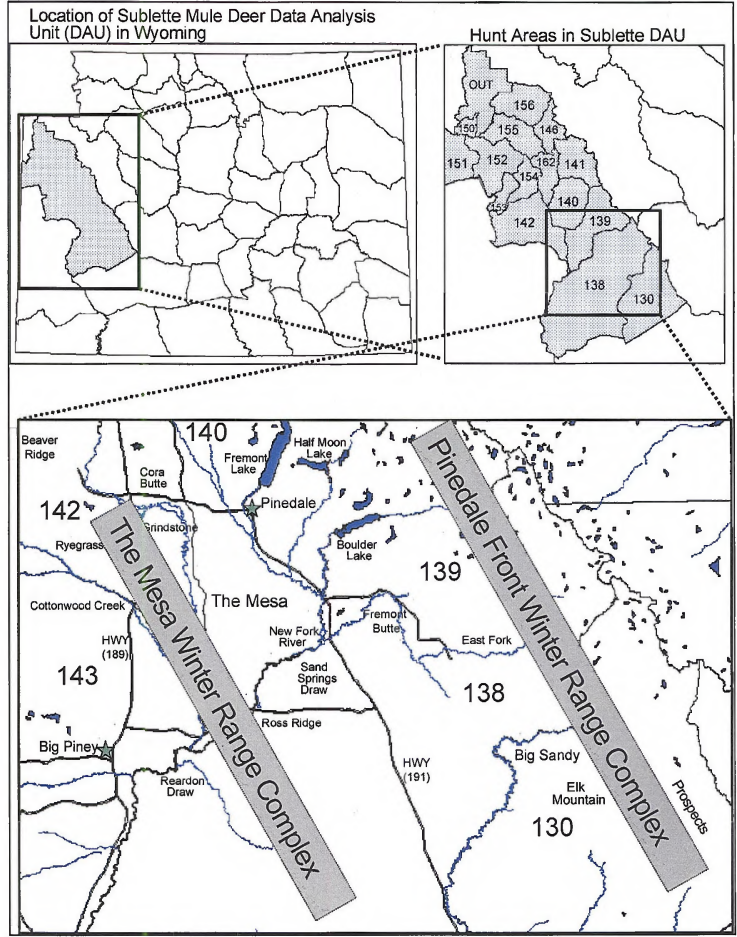

Figure 2.1 Location of the Sublette Mule Deer Data Analysis Unit, Wyoming Game and Fish Department Hunt Areas, and the Mesa and Pinedale Front Winter Range Complexes.

Because the PAPA encompasses most of the MWRC, which is used by thousands of mule deer, pronghorn, and sage grouse, development of this area may have adverse impacts on wildlife. Impacts to wildlife species may be defined as the change in a population's reproduction and/or survival caused by some disturbance (Anderson 1999). Determining the impact(s) of energy development on wildlife populations is best determined through long-term studies where pre-development data, such as, survival 
-

-

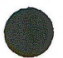


and reproduction are available. Because these studies are by necessity observational, determining cause and effect relationships is very difficult. Simply documenting a behavioral response (e.g., avoidance, acclimation, dispersal) to a disturbance adds very little to our knowledge of the impact, if it cannot be linked to the survival or reproductive success of the species involved. And conversely, documenting a change in reproduction or survival does not add to our knowledge of the impact if the cause (e.g., weather, habitat loss, disease) of the change cannot be determined. Because of the difficulty with designing and funding long-term studies, impacts of energy development on free-ranging ungulate populations are poorly understood, and often debated. However, both direct and indirect impacts associated with energy development have the potential to affect ungulate population dynamics, particularly when disturbances are concentrated on winter ranges, where energetic costs are great and animals occur at high densities. Direct impacts include the loss of habitat to well pads, access roads, and pipelines. Indirect impacts may include changes in distribution, stress, or activity caused by increased human disturbances associated with energy development (i.e., traffic, noise, human presence).

The major shortcoming of efforts to evaluate the impact(s) of disturbances on wildlife populations is that they seldom are addressed in an experimental framework, but rather tend to be short-term and are always observational. Brief, post-development monitoring plans associated with regulatory work generally result in little or no information that allow agencies and industry to assess impacts on wildlife or identify new, potentially more effective, mitigation measures. On the other hand, long-term studies are difficult to implement because they are expensive and require interagency and industry cooperation and commitment. Additionally, the acquisition of pre-development data on movement patterns and population characteristics, and identification of suitable control and treatment areas is extremely uncommon. However, the situation in the PAPA and upper Green River Basin is unique because all the necessary information is available to conduct a well-designed $\mathrm{BACl}$ study to suggest how or if natural gas development affects the PAPA mule deer population.

To assess the potential effects of energy development on mule deer in the PAPA, we proposed a BeforeAfter Control-Impact (BACl) study design (Green 1979, McDonald et al. 2000, Morrison et al. 2001), where a second population, or subpopulation isolated from development activities (control area) is studied during the same time period and subjected to the same environmental conditions as the PAPA population (treatment area). The basic idea with $\mathrm{BACl}$ is that a potentially impacted site is sampled both before and after the time of the disturbance (e.g., energy development), and one or more control sites that do not receive any disturbance are sampled at the same time. The assumption is that any naturally occurring changes will be similar at the control and treatment sites, and in the absence of the treatment the parameters of interest will be similar for both areas, or at least the magnitude of the differences will be relatively constant from year to year. Thus, potential changes at the treatment site may be attributed to the disturbance (Manly 2001). It is not critical that the control and treatment populations be identical, only that the subpopulations are independent and that both respond to the same environmental factors. Thus, the expected difference between the two populations if no impact occurs is constant through time.

Among environmental field studies, $\mathrm{BACl}$ designs are often preferred because they incorporate both time and control sites, thereby minimizing chances that unmeasured variables (e.g., weather, vegetation) influence observed effects (McDonald et al. 2000). If either the time or geographic control were left out of the design, interpretation of the results would be open to question and easily impeached. Although strict causation cannot be inferred with any observational study, including BACl studies, interpretation and construction of a weight of evidence argument for causation is often facilitated with results from a $\mathrm{BACl}$ analysis (McDonald et al. 2000).

For example, a decrease in survival, reproduction, and/or density of both populations at the time of energy development would indicate the decrease was not a result of energy development, rather some other factor such as drought, severe winter, or disease. If, however, survival and reproduction of the population occupying the treatment area decreases while the control area remains relatively unchanged, then evidence begins to form that suggests decreased survival and reproduction may be attributed to 
energy development. Again, this does not demonstrate a cause-effect relationship; rather it is simply one piece in a weight of evidence approach, where the $\mathrm{BACl}$ study design examines several direct (e.g, survival) and indirect (e.g., habitat use, displacement) parameters that are statistically analyzed and carefully interpreted.

For this study design, energy development in the MWRC will be the treatment and a portion of the PFWRC will serve as a control. The PFWRC consists mostly of federal lands located along the southwest portion of the Wind River Range, where no energy development is anticipated. The PFWRC is an ideal control site because: 1) there is little or no exchange of deer between the MWRC and PFWRC, 2) the two deer subpopulations use separate winter ranges, but share common transition and summer ranges, so they have comparable foods available during parturition and arrive on winter ranges in similar condition, 3) although the two deer subpopulations occupy distinct winter ranges, they are in close proximity to one another (15-30 miles), so both are exposed to similar weather patterns and environmental conditions, 4) habitat characteristics on both winter ranges are similar and dominated by sagebrush communities, and 5) population characteristics of the two subpopulations have consistently tracked one another prior to development of the PAPA.

We believe it is essential to monitor 4 population parameters to detect potential impacts of energy development on mule deer: 1) adult doe survival, 2) over-winter fawn survival, 3) reproduction, and 4) density. As these four parameters are measured in treatment and control areas, comparisons can be made, and over time, the potential impacts of energy development on mule deer may be assessed. If mule deer in the PAPA continue to function as well as those in the control area it will suggest that energy development has no adverse impacts on mule deer in the region. If however, mule deer survival or reproduction in the PAPA decreases, while mule deer in the control area remains unchanged, then energy development may be the cause of those declines. For the $\mathrm{BACl}$-designed monitoring plan, the number of radio-collared deer may refine the quality of the measurement (i.e., survival) taken, but the sample size $(n)$ for determining the treatment effect is the number of years.

Results from Phase I identified seasonal migration routes and distribution of deer in the MWRC and PFWRC portions of the Sublette DAU. Although mule deer migrations of $>60$ miles have been reported in parts of Idaho (Thomas and Irby 1990) and Montana (Mackie et al. 1998), mule deer on and adjacent to the PAPA are likely the most migratory deer herd in the western states, annually migrating 60-100 miles between winter and summer ranges. Because these deer are highly mobile and demonstrate strong fidelity to seasonal ranges, the potential for energy development, or other human disturbances, to disrupt migratory routes and/or winter distribution patterns exists. While changes in distribution or migratory patterns may not necessarily result in decreased deer survival or reproduction, it is useful to include within the monitoring plan to: 1) document if migration routes remain intact, 2) document if deer continue using pre-development winter ranges, 3 ) provide industry and agencies with accurate, precise movement data for site-specific analyses (e.g., range designation, directional drilling vs. single pad), 4) identify mitigation opportunities on and off-site treatment and control areas (e.g., migration corridors, habitat improvements), and 5) allow for analyses (e.g., resource selection) of winter range preference among treatment and control areas.

Properly designed long-term monitoring and examination of adult survival, over-winter fawn survival, reproduction, density, and seasonal distribution/movement patterns will allow for population-level inferences concerning the potential impacts of energy development on mule deer. 


\subsection{METHODS}

\subsubsection{Deer Capture}

Helicopter net-gunning was used to capture deer across winter ranges in treatment (PAPA) and control (PFWRC) areas. Both GPS and VHF collars were equipped with mortality sensors that change pulse rate if the collar remains stationary for more than 8 hours. The VHF collars were dutycycled to transmit signals October 1 through May 31. The GPS collars were store-on-board units capable of storing approximately 3,000 locations and programmed to obtain fixes every 2 hours during winter months (November-April). Additionally, they were equipped with remote release mechanisms programmed to activate at a specified time, so that collars could be retrieved and data downloaded.

\subsubsection{Winter Movement and Distribution Patterns}

Data collected from GPS-collared deer accurately identified winter distribution, movement patterns, and migration routes of the marked deer on and adjacent to winter ranges. Over time, these data will be used in conjunction with pre-development data to identify changes in mule deer movement patterns and distribution in relation to energy development activities. Because several $(n=4)$ GPS collars remained on the same deer for consecutive winters (2002-03 and 2003-04), some data will not be available until 2004.

\subsubsection{Population Characteristics}

\subsubsection{Abundance and Density Estimates}

Deer abundance and density were estimated in control (PFWRC) and treatment (PAPA) areas using aerial counts of deer in systematically sampled $1-\mathrm{mi}^{2}$ quadrat units. Winter distribution data collected from radio-collared deer in the study area between 1998 and 2000 was used to delineate sampling frames of approximately $70-\mathrm{mi}^{2}$ and $40-\mathrm{mi}^{2}$ for treatment and control areas, respectively. Sampling frames were expected to contain high-densities of deer so that stratifying was unnecessary. The number of quadrats sampled for each frame covered approximately $45 \%$ of the geographic area. Sampling frames identified in treatment and control areas contained similar habitat types and counts were conducted when both areas had similar snow cover and sightability conditions.

Counts of animals on random units assumed that all animals present were detected. Although there is overwhelming evidence that visibility bias is a substantial source of error in wildlife surveys (Samuel et al. 1992), we assumed $100 \%$ sightability and no correction factors were incorporated into population estimates. Group size and vegetative cover may significantly influence visibility bias in ungulate helicopter surveys (Samuel et al. 1987). However, sampling frames in this study area consist of homogenous sagebrush stands with no tree cover. Additionally, telemetry data from Phase I indicated male and female deer did not winter in different areas, so potential group size variation resulting from sexual segregation should not influence counts. Further, when survey areas contain large concentrations of animals that are widely distributed, recognition of individual groups may be near impossible. In these situations, attempting to determine correction factors for groups is likely not feasible (Samuel et al. 1987).

Counts were conducted from a piston-powered Bell helicopter flown approximately 100-150 feet above ground and at speeds of 20-40 knots. The northeast UTM coordinate for each quadrat were programmed into a global positioning unit (GPS) on the helicopter. Quadrat perimeters were then flown clockwise, such that the observer was positioned on the inside, while the pilot navigated. A real-time flight path was traced into the on-board GPS and once the perimeter was established, quadrat interiors were systematically searched. Observer and navigator collectively detected deer groups and determined whether groups were inside our outside quadrat boundaries. Deer detected inside and moving out were 
considered in the quadrat, while deer detected outside and moving in the quadrat were considered out. Half of the deer detected along perimeter boundaries were considered in the quadrat. For each quadrat, the observer recorded number of deer, number of deer groups, and total search time.

\subsubsection{Reproduction}

Doe:fawn ratios are commonly used as an index to herd productivity or reproduction. Doe:fawn ratios were calculated from composition data collected during the WGFD's annual helicopter surveys in December, consistent with the previous 10 years of WGFD data collection (WGFD 2002). Sample sizes were adequate to obtain desired levels of precision in ratio estimates (Czaplewski et al. 1983).

\subsubsection{Over-winter Fawn Survival}

Deer from both the MWRC and PFWRC congregate on the northern ends of their respective winter ranges every spring and allow large numbers $(>1,000)$ of animals to be counted and classified. Ground-based composition surveys conducted in April were used to calculate post-winter adult:fawn ratios. These data were used in conjunction with adult survival rates and December adult:fawn ratios to estimate over-winter fawn survival, using the change-in-ratio estimator from White et al. (1996):

$$
\begin{aligned}
\hat{S}_{f}=\hat{S}_{a} x \frac{B}{A}, \text { where } A & =\text { count of December fawns/count of December adults } \\
B & =\text { count of April fawns/count of April adults } \\
\hat{S}_{a} & =\text { estimate of adult survival }
\end{aligned}
$$

Adult survival rates were estimated from telemetry records, rather than carcass counts. The delta method was used to estimate variance.

\subsubsection{Adult Winter Survival}

Adult doe survival was estimated from telemetry records using the Kaplan-Meier procedure (Kaplan and Meier 1985). A minimum of 30 marked deer was maintained in both control and treatment areas.

\section{$\underline{2.2 .4}$ Resource Selection}

Resource selection, as described by Manly et al. (2002), is a rapidly advancing methodology for analyzing, modeling, and interpreting wildlife field studies. Resource selection analyses have broad applications, and in the case of this study, will be used to determine how mule deer use their habitats in relation to various habitat features, including well pads and road networks associated with energy development. 


\subsection{RESULTS}

\subsubsection{Deer Capture}

We captured and radio-collared 54 adult female deer on December 19-20, 2002. Deer capture in the PAPA was restricted to those areas where deer congregate across the north end of the PAPA in early winter, as they move onto the Mesa from Trapper's Point and/or the Ryegrass/Grindstone area. We assumed this represented a random sample of deer in the subpopulation because the deer were congregated on the north end, before they moved south to their respective winter ranges. For the same reason, deer capture in the PFWRC was restricted to the Big Sandy area; bounded to the north and west by the Big Sandy River, east to the Prospects, and south to Elk Mountain. Of the 54 deer captured, 14 were equipped with GPS radio-collars and 40 equipped with traditional VHF radiocollars. All GPS collars were store-on-board units equipped with VHF transmitters on 24-hour duty cycles, 8-hour mortality sensors, and remote-release mechanisms programmed to drop collars at 0800 hours on April 15, 2002. The programming schedule for collars was as follows:

Generation II GPS collars:

- obtain 1 location every 3 hours December 20, 2002-April 15, 2003

- obtain 1 location every 3 hours December 20, 2003-April 15, 2004

- for a possible $\sim 1,800$ locations

Generation III GPS collars:

- obtain 1 location every 2 hours December 20, 2002-April 15, 2003

- obtain 1 location every 2 hours November 01, 2003-April 15, 2004

- for a possible $\sim 3,300$ locations

We plan to maintain a sample size of 30 deer in each area, including 10 GPS and 20 VHF radio-collars.

\subsubsection{GPS Data Collection}

We intended to collect data from 15 GPS collars during 2003. Of the 15, six were collars that failed to release in 2002 and nine were captured in December 2002 and programmed to release in April 2003. Three fixed-wing telemetry flights (February 21, March 24, April 11) were conducted prior the April 15 release date to determine deer distribution and mortality status. Fourteen deer were located during each flight and VHF pulse rates indicated collars were functioning properly. All nine release mechanisms successfully dropped collars on April 15, 2003. However, retrieval of the six releasefailed collars proved extremely difficult because it required locating the individual deer and netgunning it from a helicopter. The net-gunning was not particularly difficult, but locating deer was problematic because of the mild spring and early migrations. We managed to recapture four of these deer. Of the two not captured, one (\#860) could not be found and another (\#863) had moved too far north for our capture effort to operate effectively. (Note: \#860 was found late in the summer and returned to Telonics, Inc. for data download. The data was retrieved, but not included in this report. Additionally, we located \#863 several times during the 2003 summer and plan to retrieve the collar during the upcoming winter capture.)

Of the 13 collars that were retrieved, six were Generation III and seven were Generation II. All collars functioned properly and collected the expected number of locations. Generation II and Generation III collars averaged 926 and 1,460 successful fix attempts, respectively. Consistent with GPS performance in previous years (Sawyer et al. 2002), success rates for GPS fix attempts were very high ( $99 \%$ ) and locations precise ( $80 \% 3-D$ locations; i.e., $\geq 4$ satellites used to determine location). Even without Selective Availability, 3-D locations typically have less than 20-meter error (Di Orio et al. 
2003).

\subsubsection{Winter Movement and Distribution Patterns}

\subsubsection{Treatment Area (PAPA):}

Individual maps were generated for six GPS-collared deer captured in the treatment area (Figures 2.2-2.7). Although we attempted to maintain 10 GPS collars in the treatment area, data from four collars were not mapped because:

$>\# 860$ could not be located during the helicopter recapture. However, it was later found and recovered in August, 2003.

$>$ \#863 was not recaptured because it had moved too far north to efficiently capture with helicopter.

$>$ \#864 died prior to the winter.

$>$ \#865 was programmed to release in April, 2004.

Deer locations were color-coded by month so that timing of winter movements and distribution patterns could be easily deciphered (Figures 2.2-2.7). Distribution and movement patterns were variable among deer. Unlike previous years, where deer shifted areas of use through the winter and utilized a large portion of the Mesa (Sawyer and Lindzey 2001, Sawyer et al. 2002), distribution during the 2002-03 winter was largely restricted to the northern portion of the Mesa. Collars $(n=3)$ carried on the same deer for two consecutive winters clearly illustrate the difference in distribution patterns among years, with deer wintering farther north during 2002-03 (Figures 2.8-2.9).

In addition to occupying areas farther north than previous years, deer in PAPA also migrated to transition ranges (e.g., Cora Butte) earlier. Two deer (\#866 and \#868) captured on the PAPA in December moved north to Cora Butte in January. Another three migrated in March, and one remained on the PAPA through April 15. Consistent with previous years, all deer traveled to the Cora Butte area via the Trapper's Point Bottleneck (TPB) (Sawyer and Lindzey 2001, Sawyer et al. 2002). Rates of deer movement in and near the TPB increased, as evidenced by distance between locations (Figures 2.2, 2.4-2.7).

Figure 2.10 includes locations $(n=6,588)$ from all six deer and illustrates the importance of BLM lands to this mule deer population. Boundaries between private and BLM lands generally correspond with habitat type and topography; with private lands consisting of flat river bottoms and agricultural areas, whereas BLM lands contain sagebrush hills in drier, more rugged terrain. Mule deer demonstrated a strong affinity to the sagebrush-dominated BLM lands.

Additionally, Figure 2.10 clearly defines the Trapper's Point Bottleneck (TPB), located 7 miles west of Pinedale, near the junction of US 191, WYO 352, and CR 110. Sawyer and Lindzey (2001) defined bottlenecks as "those areas along migration routes where topography, vegetation, development and/or other landscape features restrict animal movements to narrow or limited regions." Bottlenecks create management concerns because the potential to disrupt or threaten established migratory routes are much greater in these areas. This naturally-occurring bottleneck is approximately 1 mile in width and length, restricted to the southwest by the Green River riparian complex and to the northeast by the New Fork/Duck Creek riparian complex. Sagebrush habitats north and south of US 191 are used extensively by mule deer during certain times of the year (Sawyer and Lindzey 2001). Mule deer use the narrow strip of sagebrush connecting the 2 areas to cross U.S. Highway 191. Development of small, fenced house lots adjacent to BLM lands has narrowed the effective width of the TPB to $<1 / 2$ mile. 


\subsubsection{Control Area (PFWRC):}

Locations $(n=7,190)$ from six GPS-collared deer captured in the control area were plotted to identify winter distribution and movement patterns (Figure 2.11). Similar to the treatment area, we attempted to maintain 10 GPS collars in the control area. Data from four collars were not mapped because:

$>\# 872$ died shortly after capture.

$>\# 873, \# 874$, and \#871 were programmed to release in April 2004.

Deer locations were color-coded by month so that timing of winter movements and distribution patterns could be easily deciphered (Figure 2.11). Distribution and movement patterns were variable among deer. Consistent among deer was their mobility and tendency to shift areas of use through the winter. Core winter areas (December-March) used by individual deer ranged from $10-40 \mathrm{mi}^{2}$. Prior to the northerly migration, half the marked deer moved outside the control area in January and February to peripheral areas (i.e., Elk Mountain and The Prospects). This distribution pattern was evident for the entire subpopulation during the helicopter block counts conducted in February (see Abundance and Density Estimates)

Most deer $(n=5)$ began migrating north along the Pinedale Front in early March. Deer that winter along the Pinedale Front were known to migrate northerly along the Wind River Range to the New Fork Lake area before shifting their migration in a westerly route towards the Hoback Basin and adjacent mountain ranges (Sawyer and Lindzey 2001). However, details of this migration route, in terms of size, width, specific location, and deer fidelity were unknown prior to GPS data collected this year. All six GPS-collared deer captured in the control area migrated along what appeared to be a distinct movement corridor located at the base of the Wind River Range. While deer sometimes remained in one area for a number of days, they appeared to follow a well-defined route that rarely exceeded 1-mile in width and covered a distance of 50 miles.

The route deer followed from the control area near Buckskin Crossing took them north across the Big Sandy River, then northerly across the sagebrush flats below Sheep Creek and Muddy Creek. Deer then moved into slightly rougher terrain among the boulders and sagebrush draws east of CR 353, south of the East Fork, and west of Irish Canyon. Deer then moved northerly, crossing the East Fork and Pocket Creek approximately 2-3 miles east of CR 353. Once across Pocket Creek, deer contoured through the sagebrush slopes and aspen pockets, northerly through Cottonwood Creek and Silver Creek. From Silver Creek, deer continued northwesterly across Lovett and Scab Creek. Deer continued to contour across the sagebrush slopes below Soda Lake, towards the outlet of Boulder Lake. Deer crossed Boulder Creek near the outlet of Boulder Lake, and then moved north to Fall Creek, apparently to avoid an agricultural area between Fall Creek and Pole Creek. Deer crossed Fall Creek just below the confluence of Meadow Creek, and then moved northwesterly toward the outlet of Fremont Lake. Deer crossed Pine Creek at the Fremont Lake Bottleneck, as described by Sawyer and Lindzey (2001). After moving through the Fremont Lake Bottleneck, deer moved north along the Willow Creek Road and Fremont Ridge. Deer moved within $1 / 2$ mile either side of the Willow Lake Road from Soda Lake to the outlet of Willow Lake. GPS collars were released on April 15, 2003 and no movements were recorded beyond the outlet of Willow Lake. 
-

-

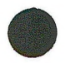




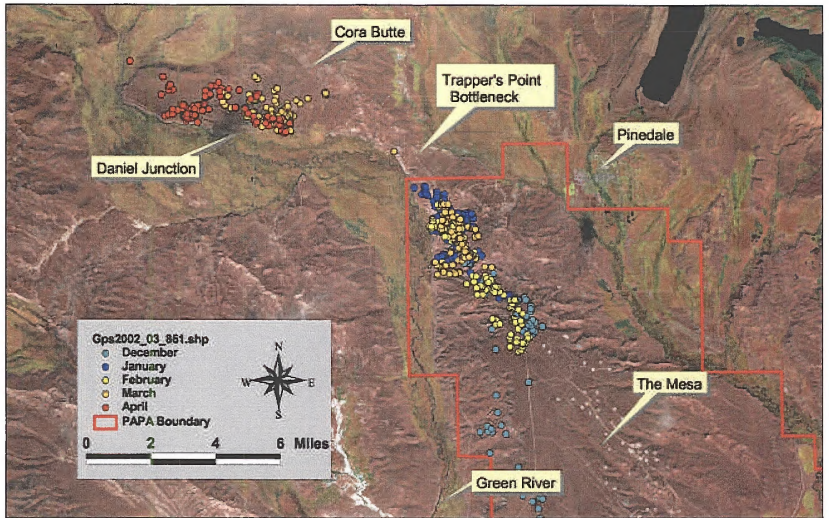

Figure 2.2 GPS locations of deer \#861 in the Pinedale Anticline Project Area (PAPA), December 20, 2002 - April 15, 2003.

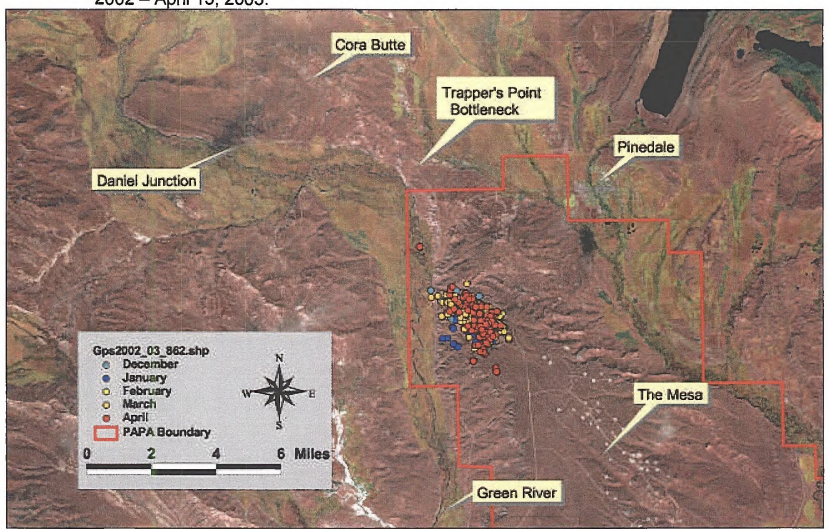

Figure 2.3 GPS locations of deer \#862 in the Pinedale Anticline Project Area (PAPA), December 20, 2002 - April 15, 2003. 

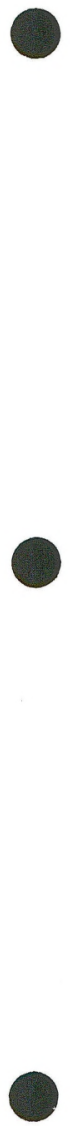


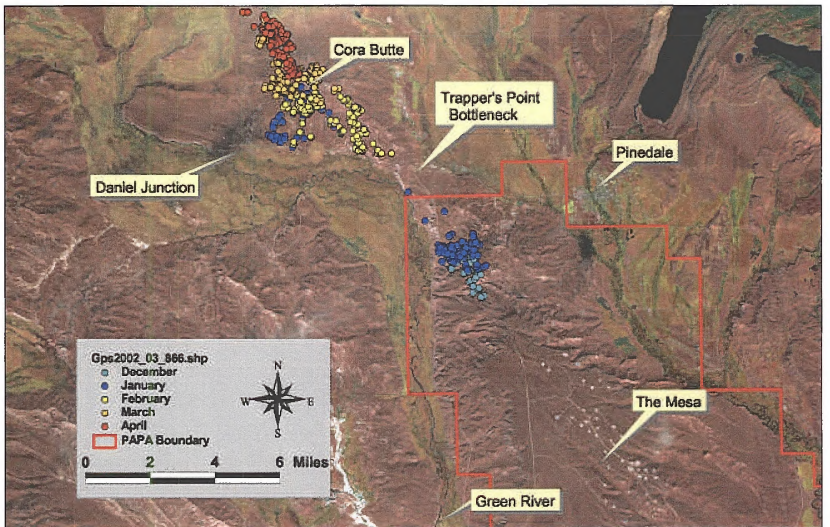

Figure 2.4 GPS locations of deer \#866 in the Pinedale Anticline Project Area (PAPA), December 20, 2002 - April 15, 2003.

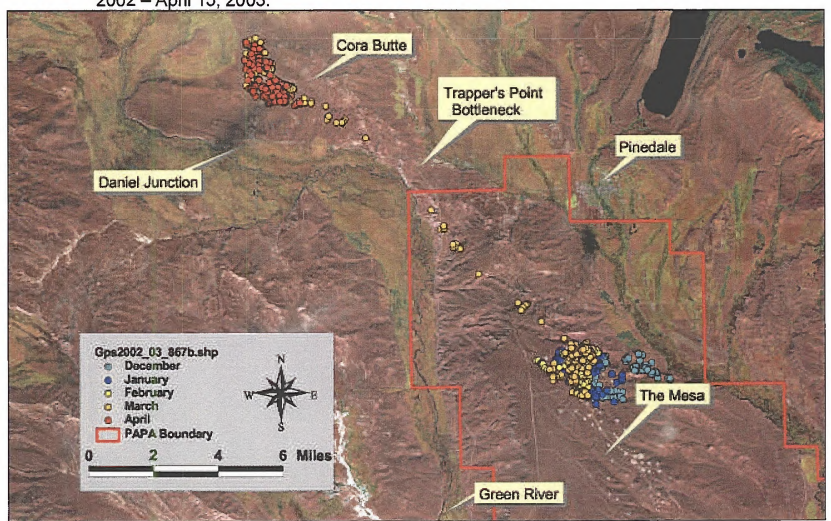

Figure 2.5 GPS locations of deer \#867b in the Pinedale Anticline Project Area (PAPA), November 1, 2002 - April 15, 2003. 


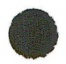

-

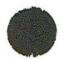




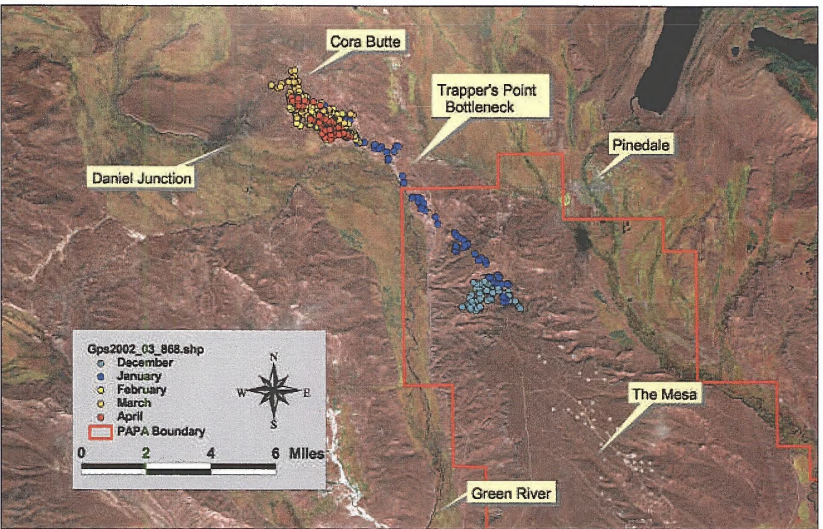

Figure 2.6 GPS locations of deer \#868 in the Pinedale Anticline Project Area (PAPA), December 20, 2002 - April 15, 2003.

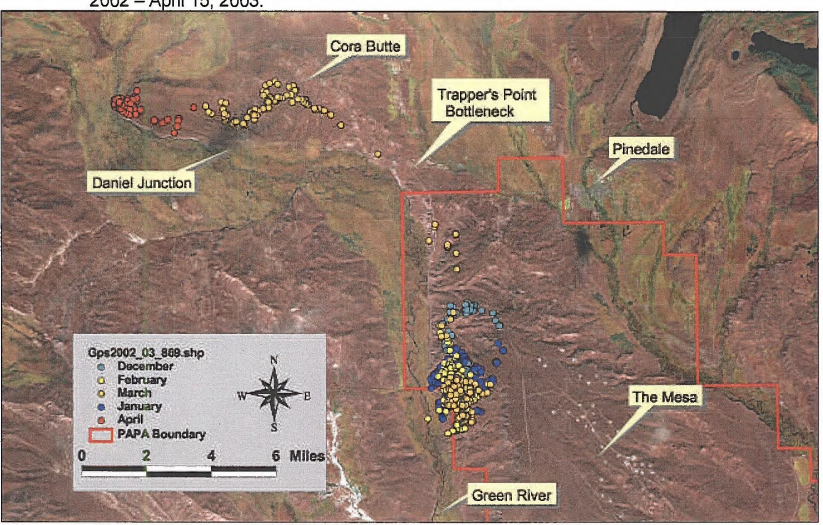

Figure 2.7 GPS locations of deer \#869 in the Pinedale Anticline Project Area (PAPA), December 20, 2002 - April 15, 2003. 
-

-

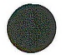




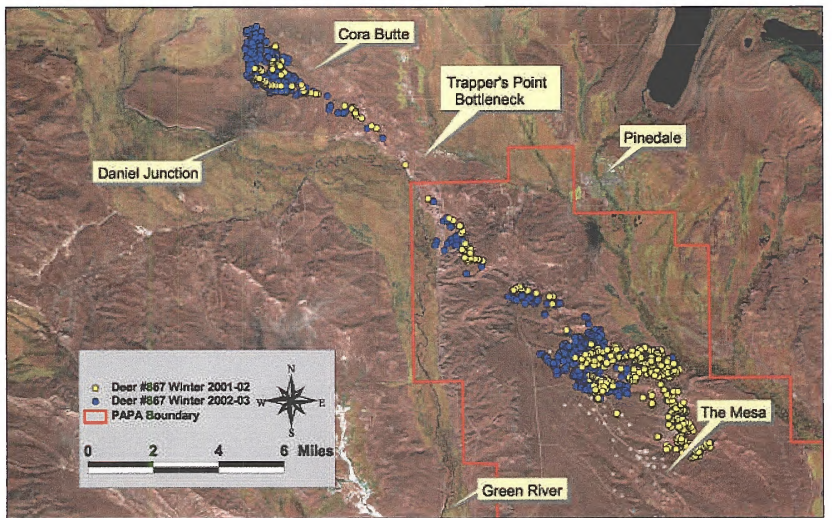

Figure 2.8 GPS locations of deer \#867b in the Pinedale Anticline Project Area (PAPA), December 20, 2001 - April 15, 2002 (yellow) and December 20, 2002 - April 15, 2003 (blue).

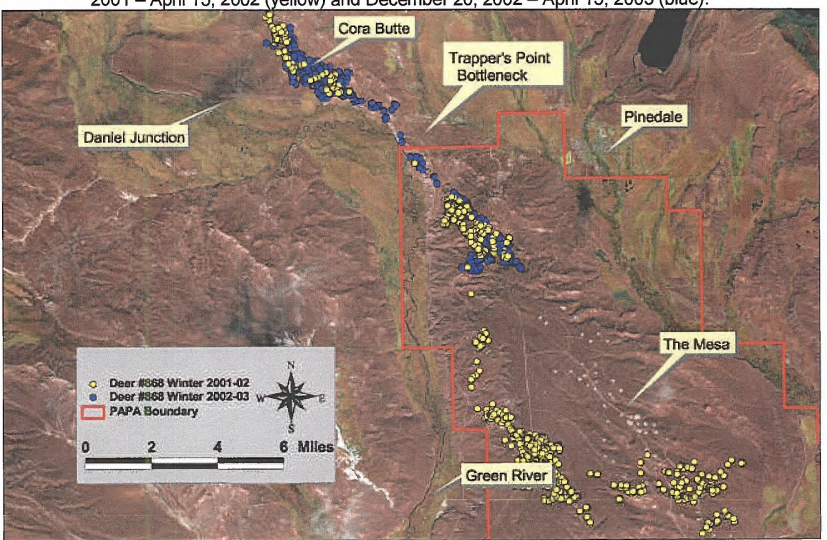

Figure 2.9 GPS locations of deer \#868 in the Pinedale Anticline Project Area (PAPA), December 20, 2001 - April 15, 2002 (yellow) and December 20, 2002 - April 15, 2003 (blue). 
-

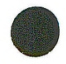

- 

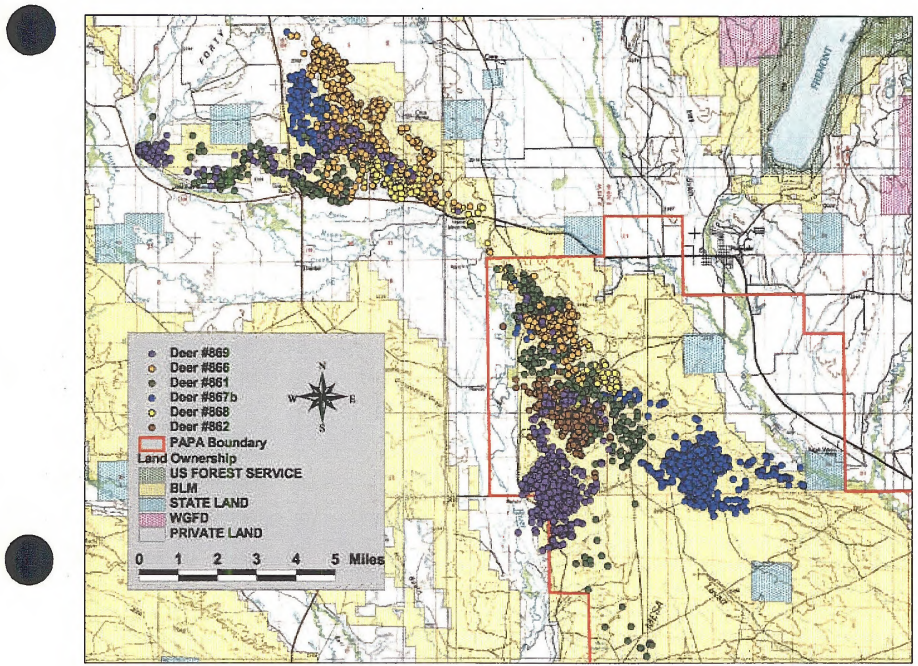

Figure 2.10 GPS locations of all deer $(n=6)$ and land ownership of the Pinedale Anticline Project Area (PAPA), December 20, 2002 - April 15, 2003. 
-

-

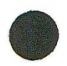




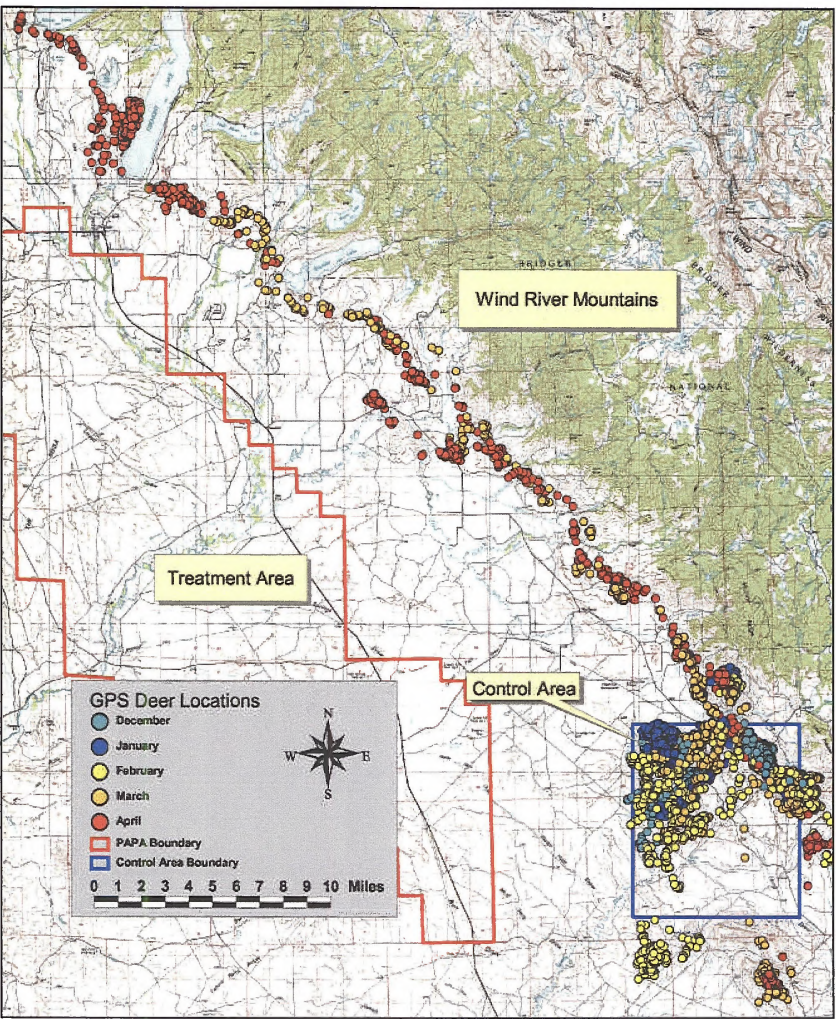

Figure 2.11 GPS locations $(n=7,190)$ of six deer captured in the control area along the Pinedale Front, December 20, 2002 - April 15, 2003. 
-

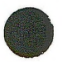

- 


\subsubsection{Population Characteristics}

\subsubsection{Abundance and Density Estimates}

Deer abundance and density in control and treatment areas were estimated using counts of deer in randomly selected $1-\mathrm{mi}^{2}$ quadrat units. Sampling frames of 74- $\mathrm{mi}^{2}$ and $38-\mathrm{mi}^{2}$ were identified for treatment and control areas, respectively (Figure 2.12). However, several quadrats inaccurately identified as high density areas were dropped from each area, resulting in sampling frames of $69-\mathrm{mi}^{2}$ and $36-\mathrm{mi}^{2}$. The number of quadrats sampled for each frame represented approximately $45 \%$ of the geographic area, 32 for the treatment and 16 for the control. Helicopter flights were conducted on February $6-7,2003$ to count deer in selected quadrats. Average flight time per quadrat was 10 minutes. Estimated deer abundance $(\hat{N})$ in the treatment area was $4,888 \pm 1,077$, while deer density $(\hat{D})$ was 71 $\pm 16 \mathrm{deer} / \mathrm{mi}^{2}$ (Table 2.1). Estimated deer abundance $(\hat{N})$ in the control area was $1,910 \pm 533$, while deer density $(\hat{D})$ was $53 \pm 15$. Coefficient of variation $(C V(\hat{N}))$ for treatment and control areas was $13 \%$ and $18 \%$, respectively. Refer to Appendix $A$ for equations used to calculate summary statistics.

Table 2.1 Summary statistics for abundance and density estimates for treatment and control areas, February 2002 and 2003.

\begin{tabular}{|c|c|c|c|c|}
\hline Summary Statistics & \multicolumn{2}{|c|}{$\begin{array}{c}\text { Treatment Area } \\
\text { (Pinedale Anticline Project Area) }\end{array}$} & \multicolumn{2}{|c|}{$\begin{array}{c}\text { Control Area } \\
\text { (Pinedale Front) }\end{array}$} \\
\hline Year & 2002 & 2003 & 2002 & 2003 \\
\hline Total Quadrats $(U)$ & 84 & 69 & 42 & 36 \\
\hline Quadrats Sampled $(u)$ & 21 & 32 & 10 & 16 \\
\hline Deer Counted $(N)$ & 1,511 & 2,267 & 1,033 & 849 \\
\hline Density Estimate $(\hat{D})$ & 72 & 71 & 103 & 53 \\
\hline Variance $(\operatorname{Var}(\hat{D}))$ & 132 & 90 & 277 & 87 \\
\hline Standard Error $(\operatorname{SE}(\hat{D}))$ & 11.49 & 9.49 & 16.64 & 9.34 \\
\hline $90 \%$ Confidence Interval & $(53,91)$ & $(55,87)$ & $(76,130)$ & $(38,68)$ \\
\hline Abundance Estimate $(\hat{N})$ & 6,044 & 4,888 & 4,339 & 1,910 \\
\hline Variance $(\operatorname{Vâr}(\hat{N}))$ & 931553 & 428656 & 488690 & 113083 \\
\hline Standard Error $(\operatorname{SE}(\hat{N}))$ & 965 & 655 & 699 & 336 \\
\hline $90 \%$ Confidence Interval & $(4456,7632)$ & $(3811,5965)$ & $(3189,5489)$ & $(1357,2463)$ \\
\hline Coefficient of Variation $(C V(\hat{N}))$ & $16 \%$ & $13 \%$ & $16 \%$ & $18 \%$ \\
\hline
\end{tabular}

Density estimates in the treatment area were consistent between 2002 and 2003 . However, deer densities found in the control during 2003 were much lower (49\%) than 2002 . Based on GPS-collar data, $33 \%$ of deer captured in the control area moved out prior to the helicopter surveys conducted in early February. Early deer movements likely explain much of the reduction, however deer density appeared to decline in the control area between 2002 and 2003. These findings were consistent with the 2002 WGFD counts, which had much lower encounter rates $(-14 \%$ and $-26 \%$, respectively) in HA's 130 and 138 , along the Pinedale Front (Appendix B).

Compared with 2002, abundance estimates were lower in both the treatment and control areas. However, the sampling frames for each area were smaller in 2003 (e.g., 84 quadrats in 2002 versus 69 in 2003), resulting in smaller abundance estimates. 


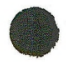

-

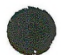




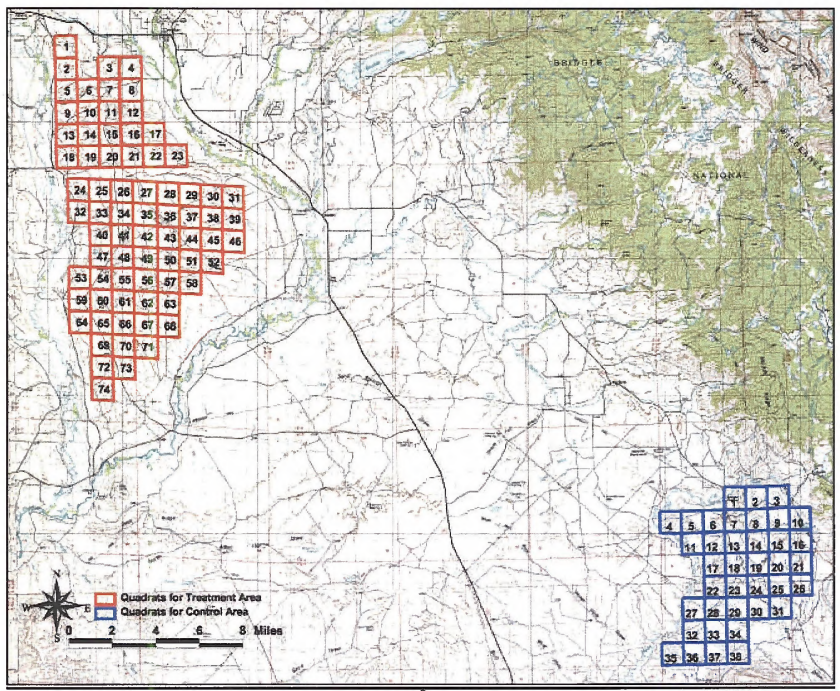

Figure 2.12 Location of sampling frames and 1- $\mathrm{mi}^{2}$ quadrats used to calculate abundance and density estimates for control and treatment areas.

\subsubsection{Reproduction}

The WGFD conducted helicopter composition (buck:doe:fawn) surveys for the Sublette Mule Deer DAU to collect pre-winter (December) information on the sex (i.e., buck or doe) and age (i.e., fawn or adult) structure of the population (Appendix B). A total of 8,156 deer were counted in December, 2002, including 2,778 on the MWRC and 5,378 on the PFWRC (WGFD 2002; Tables 2.3-2.4). Estimated fawn:doe ratios were $64: 100$ and $65: 100$, respectively (Table 2.2), slightly lower than the 10-year averages. Treatment and control areas have displayed similar trends in reproduction (fawn:doe ratios) prior to and since the PAPA ROD in 2000 (Figure 2.13).

\subsubsection{Over-winter Fawn Survival}

The WGFD conducted ground-based composition (adult:fawn) surveys for the Sublette Mule Deer DAU to estimate post-winter fawn:adult ratios (Appendix B). During April of 2003, survey data was collected for both the MWRC and the PFWRC. A total of 1,959 and 958 deer were counted in the MWRC and 


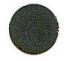

-

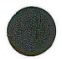


PFWRC, respectively (Tables 2.3-2.4). Estimates of over-winter fawn survival were 0.57 and 0.68 in the MWRC and PFWRC, respectively (Tables 2.3-2.4). Compared to the control area, over-winter fawn survival has generally been lower in the treatment area since the PAPA ROD in 2000 (Figure 2.14).

Table 2.2 Mule deer population characteristics measured for treatment (MWRC) and control (PFWRC) areas by Wyoming Game and Fish Department, 1992-2003.

\begin{tabular}{|c|c|c|c|c|c|c|c|c|}
\hline & Treatment & Control & Treatment & Control & Treatment & Control & Treatment & Control \\
\hline Year & $\begin{array}{c}\text { fawn:doe } \\
\text { December }\end{array}$ & $\begin{array}{l}\text { fawn:doe } \\
\text { December }\end{array}$ & $\begin{array}{l}\text { fawn:adult } \\
\text { December }\end{array}$ & $\begin{array}{l}\text { fawn:adult } \\
\text { December }\end{array}$ & $\begin{array}{c}\text { fawn:adult } \\
\text { April }\end{array}$ & $\begin{array}{c}\text { fawn:adult } \\
\text { April }\end{array}$ & $\begin{array}{c}\% \text { ch a nge } \\
\text { overwinter }\end{array}$ & $\begin{array}{l}\text { \% change } \\
\text { overwinter }\end{array}$ \\
\hline $1992-93$ & 62 & 61 & 44 & 42 & 24 & 12 & 45 & 73 \\
\hline 1993-94 & 47 & 51 & 36 & 39 & 29 & 23 & 19 & 40 \\
\hline $1994-95$ & 61 & 72 & 45 & 54 & 41 & 50 & 8 & 7 \\
\hline \begin{tabular}{|l|}
$1995-96$ \\
\end{tabular} & 56 & 63 & 45 & 45 & 24 & 33 & 48 & 26 \\
\hline 1996-97 & 73 & 75 & 52 & 55 & 32 & 36 & 39 & 34 \\
\hline $1997-98$ & 92 & 81 & 57 & 62 & 52 & 48 & 9 & 22 \\
\hline \begin{tabular}{|l|}
$1998-99$ \\
\end{tabular} & 67 & 76 & 51 & 58 & 38 & 64 & 25 & 0 \\
\hline $1999-00$ & 85 & 76 & 58 & 56 & 57 & 54 & 2 & 3 \\
\hline $2000-01$ & 85 & 81 & 59 & 63 & 44 & 54 & 26 & 14 \\
\hline $2001-02$ & 69 & 71 & 50 & 54 & 36 & 38 & 28 & 30 \\
\hline $2002-03$ & 64 & 65 & 50 & 51 & 32 & 36 & 36 & 28 \\
\hline Average & 69 & 70 & 50 & 53 & 38 & 42 & 25 & 23 \\
\hline
\end{tabular}

Table 2.3 Mule deer count data and calculations for over-winter fawn survival in the control (PFWRC), 1999-2003.

\begin{tabular}{|c|c|c|c|c|c|c|c|c|}
\hline Year & $\begin{array}{c}\text { December } \\
\text { Adults }\end{array}$ & $\begin{array}{c}\text { December } \\
\text { Fawns }\end{array}$ & $\begin{array}{c}\text { April } \\
\text { Adults }\end{array}$ & $\begin{array}{c}\text { April } \\
\text { Fawns }\end{array}$ & $A$ & $B$ & $\hat{S}_{a}$ & $\hat{S}_{f}$ \\
\hline $1999-00$ & 2698 & 1517 & 959 & 494 & 0.56 & 0.52 & 0.83 & 0.76 \\
\hline $2000-01$ & 2853 & 1769 & 955 & 478 & 0.62 & 0.50 & 0.85 & 0.69 \\
\hline $2001-02$ & 4593 & 2455 & 790 & 300 & 0.53 & 0.38 & 0.85 & 0.60 \\
\hline $2002-03$ & 3565 & 1813 & 704 & 254 & 0.51 & 0.36 & 0.96 & 0.68 \\
\hline
\end{tabular}

Table 2.4 Mule deer count data and calculations for over-winter fawn survival in the treatment (MWRC), 1999-2003.

\begin{tabular}{|c|c|c|c|c|c|c|c|c|}
\hline Year & $\begin{array}{c}\text { December } \\
\text { Adults }\end{array}$ & $\begin{array}{c}\text { December } \\
\text { Fawns }\end{array}$ & $\begin{array}{c}\text { April } \\
\text { Adults }\end{array}$ & $\begin{array}{c}\text { April } \\
\text { Fawns }\end{array}$ & $A$ & $B$ & $\hat{S}_{a}$ & $\hat{S}_{f}$ \\
\hline $1999-00$ & 2550 & 1547 & 1390 & 764 & 0.61 & 0.55 & 0.87 & 0.74 \\
\hline $2000-01$ & 2420 & 1458 & 1685 & 707 & 0.60 & 0.42 & 0.82 & 0.59 \\
\hline $2001-02$ & 2546 & 1275 & 1366 & 460 & 0.50 & 0.34 & 0.85 & 0.57 \\
\hline $2002-03$ & 1864 & 914 & 1489 & 470 & 0.49 & 0.32 & 0.88 & 0.57 \\
\hline
\end{tabular}

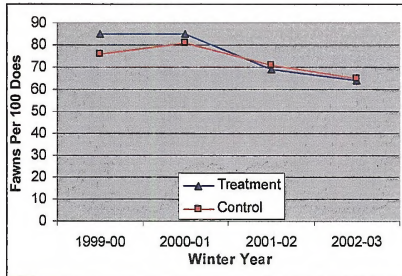

Figure 2.13 Fawn:doe ratios in treatment and control areas, 1999-2003.

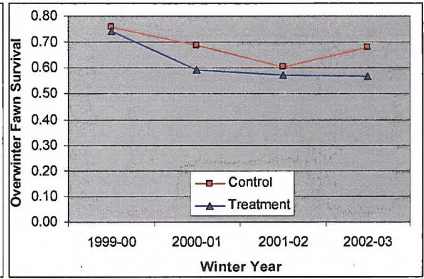

Figure 2.14 Estimated over-winter fawn survival in treatment and control areas, 1999-2003. 
-

-

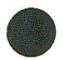




\subsubsection{Adult Winter Survival}

Winter (December 15 - May 15) survival rates were estimated using the telemetry records of 76 radiocollared adult female deer, including 36 in the treatment and 30 in the control area. Winter survival rates were 0.88 and 0.96 for the treatment and control areas, respectively (Table 2.5). Cause of death was not determined.

Table 2.5 Winter survival rates and summary statistics for adult female radio-collared deer in treatment and control areas.

\begin{tabular}{|c|c|c|c|c|c|c|}
\hline Study Area & Time Period & $N_{1}$ & $N_{2}$ & $\hat{S}$ & $90 \%$ Cl & SE \\
\hline $\begin{array}{c}\text { Pinedale Anticline } \\
\text { (Treatment) }\end{array}$ & $\begin{array}{c}\text { December 15, 2002 - } \\
\text { May 15, 2003 }\end{array}$ & 36 & 4 & 0.88 & 0.80 to 0.96 & 0.05 \\
\hline $\begin{array}{c}\text { Pinedale Front } \\
\text { (Control) }\end{array}$ & $\begin{array}{c}\text { December 15, 2002- } \\
\text { May 15, 2003 }\end{array}$ & 30 & 1 & 0.96 & 0.91 to 1.0 & 0.03 \\
\hline
\end{tabular}

$\mathrm{N}_{1}=$ number of available collars, $\mathrm{N}_{2}=$ number of deaths, $\hat{S}=$ survival estimate, $\mathrm{Cl}=$ confidence interval, $\mathrm{SE}=$ standard error

\subsubsection{Wyoming Game and Fish Department Job Completion Report}

The WGFD annually compiles and summarizes population data of the Sublette mule deer herd in a job completion report (JCR). Refer to Appendix B for the 2002 JCR.

\subsubsection{Resource Selection}

Our resource selection analysis compares habitat features of randomly selected available points to GPS locations collected from marked deer. Because some GPS-collars operate on the same deer for consecutive years, there is a lag time between when the data is collected and when it is analyzed. Resource selection analyses will not be complete until all GPS data is recovered from the 2002-03 winter. However, a substantial amount of baseline work was completed to facilitate the analysis, including:

$>$ Developed GIS grids $(30 \mathrm{~m} \times 30 \mathrm{~m})$ for slope, aspect, elevation

$>$ Developed GIS layers of road networks and well pads

$>$ Identified available area based on 30,626 GPS locations from 34 deer over a 5-year period (1998-2002)

$>$ Generated a sample of available points $(n=26,413)$ across the study area.

$>$ Clipped GPS data sets to PAPA boundary

$>$ Refined GIS procedures for extracting information on habitat variables (slope, aspect, elevation, road density, distance to well pad) from available and used points.

$>$ Developed SAS codes for correlation analysis (PROC CORR; SAS Institute 2000)

$>$ Developed SAS codes for model building (PROC GENMOD; SAS Institute 2000)

$>$ Developed procedures to produce surface maps of mule deer winter use areas. 


\subsection{DISCUSSION AND FUTURE DIRECTION}

GPS data lack the inherent bias often associated with traditional telemetry methods because they are systematically collected, irrespective of human error, habitat type, poor weather conditions, or time of day. Forest density and canopy cover may reduce the fix rates and positional accuracy of GPS collars (Rempel et al. 1995, Moen et al. 1996, D'Eon 2002, Di Orio 2003). However, the open shrublands and gentle topography of the PAPA and Pinedale Front allow for optimal satellite coverage and GPS performance. Fix-rate GPS bias associated with different habitat types has not been an issue in this study, as our GPS collars consistently demonstrate high (99\%) fix rate success and precision $(80 \% 3-$ D locations). Prior to May 2000 the most significant source of error in GPS data was due to the selective availability policy implemented by the U.S. Department of Defense (D'Eon et al. 2002). Selective availability introduced constant and unpredictable sources of error into satellite transmissions that resulted in GPS accuracy of $\pm 100 \mathrm{~m} \mathrm{95 \%}$ of the time (Wells 1986). However, since the discontinuation of selective availability, 3-D GPS locations typically have less than $20 \mathrm{~m}$ error (Di Orio 2003).

Incorporating GPS and GIS allow for the visualization, analysis, and recognition of land-use patterns of radio-collared animals across large spatial scales. Nearly 14,000 locations from 12 deer were collected from GPS collars during the 2002-03 winter. Another 6 GPS collars will be recovered in 2004 and should contain an additional 5,500 locations from the 2002-03 winter. Although data collection is delayed a full year when GPS collars operate on the same deer for two consecutive winters, acquiring movement and distribution information from the same animal over a period of years provides useful data for year-to-year comparisons. This year, for example, we were able to demonstrate that deer in the PAPA wintered farther north than in previous years. If we had not had GPS collars running consecutive winters on the same deer, it could have been argued that we captured deer that only utilized the northern PAPA. We will continue to run a portion of GPS collars on the same deer for consecutive winters.

Consistent with our findings, the WGFD also noted a more northerly distribution of deer during the 2002-03 winter (Appendix B), citing mild weather conditions. Sawyer and Lindzey (2001) described deer movements in the PAPA as generally progressing from north to south, as winter severity increases. Because of mild weather conditions and minimal snow accumulation in the PAPA, deer appeared to winter farther north than usual. The higher-elevation areas located in the north end of the PAPA (i.e., Mt. Airy, Stewart Point) were heavily utilized by GPS-collared deer; areas that often become inaccessible during periods of high snow accumulations.

Basic distribution maps generated from GPS data illustrate winter use of the study areas, demonstrate the importance of BLM lands, and refine information on migration routes and seasonal ranges. Deer in the treatment area (PAPA) continued to utilize the Trapper's Point Bottleneck (TPB) as a migratory route between winter and spring/fall transition ranges. While rates of deer movement increased in and near the TPB, as evidenced by the distance between locations, the TPB continued to function effectively during 2002-03. Agencies, industry, NGO's, and the public recognize the value of maintaining this movement corridor for the Sublette deer herd. Land-use decisions in and adjacent to the TPB should consider the migration routes and seasonal ranges of the Sublette deer herd.

Deer distribution and winter movement patterns in the control area (PFWRC) were variable. While most locations occurred within the area delineated as the control, deer moved about freely in all directions prior to spring migration; south to Elk Mountain, southeast along the Big Sandy, easterly to the Prospects, and northerly along the foothills of the Wind River Range. The ability to alter their rates of movements, to change their pathways, and occupy a variety of winter habitats as needed are behaviors that likely allow deer to best exploit winter ranges. Although winter distribution patterns varied among deer, the migration route to northerly transition and summer ranges was surprisingly consistent. All six GPS-collared deer captured in the control area migrated along what appeared to be a distinct movement corridor located 
at the base of the Wind River Range. Deer followed a well-defined route that rarely exceeded 1-mile in width and covered a distance of 50 miles. Deer that winter in the PFWRC were known to migrate northerly along the Wind River Range to the New Fork Lake area, before shifting their migration in a westerly direction towards the Hoback Basin and adjacent mountain ranges (Sawyer and Lindzey 2001). However, details of this migration route, in terms of size, width, specific location, and deer fidelity were unknown prior to GPS data collected this year. Although these deer may migrate 100 miles between winter and summer ranges (Sawyer and Lindzey 2001), our GPS collars only recorded movements prior to April 15. Deer management in the Sublette DAU is complicated by the long-distance migrations that occur through a variety of habitats and across a mix of land ownership. However, as more GPS data is collected and the migration corridor becomes clearly defined, agencies will have the necessary information to maintain deer movements through the PFWRC, adjust harvest strategies accordingly, and prioritize habitat enhancement projects. Continued use of GPS collars appears to be the most logistically and economically effective means to collect accurate, precise winter movement and distribution data of deer.

Ultimately, distribution data from the PFWRC will be compared to distribution patterns in the PAPA to better understand potential impacts of oil and gas development. However, documenting the migratory route through the PFWRC is an excellent example of off-site mitigation. Although the BLM generally does not impose off-site mitigation on leases, movement and distribution data being collected in the PFWRC is a direct result of an industry and BLM monitoring project focused on the PAPA.

Aside from basic distribution and movement maps, GPS data can be used to conduct more rigorous scientific analyses, such as resource selection studies (Manly et al. 2002) and site-specific analyses for industry (TRC Mariah 2003), agencies, or NGOs regarding permitting, stipulations, or other wildliferelated issues. Resource selection studies provide a reliable framework for measuring or predicting how animals use the study area, compared to what is available to them. These results will be presented when our GPS data sets are more complete (i.e., 2004 report).

Four population parameters were monitored to detect potential impacts of energy development on mule deer, including: 1) adult doe survival, 2) over-winter fawn survival, 3) reproduction, and 4) density. Compared to the control area, adult survival and over-winter fawn survival were lower in the treatment area. Although point estimates for these parameters were lower in the treatment area, they were not statistically different $(a=10)$. Reproduction was nearly identical among the treatment and control areas. Deer density was lower in the control than the treatment. Consistent with our findings, lower encounter rates recorded by the WGFD during their helicopter surveys, indicated deer densities were lower in the southern half of the PFWRC in 2002-03 compared to 2001-02 (Appendix B). The apparent reduction of deer density in the PFWRC was likely a result of unusual winter distribution patterns associated with the mild 2002-03 winter. Despite lower deer numbers in 2002-03, deer densities in the treatment $\left(71 \mathrm{deer} / \mathrm{mi}^{2}\right)$ and control $\left(53 \mathrm{deer} / \mathrm{mi}^{2}\right)$ were much higher than those reported in Colorado populations. Among 13 strata identified in western Colorado winter ranges, the highest reported density was 31 deer/mi ${ }^{2}$ (Freddy 2001).

As population parameters are measured, and resource selection models developed in treatment and control areas, comparisons can be made, and over time, the potential impacts of energy development on mule deer may be assessed. For this study, the number of captured deer or counted deer may refine the quality of the measurement (e.g., survival, reproduction), but the sample size (n) is the number of years. The strength of the monitoring plan and robustness of the conclusions will be determined by the number of years it is implemented. 


\subsection{PROJECT TIMELINE}

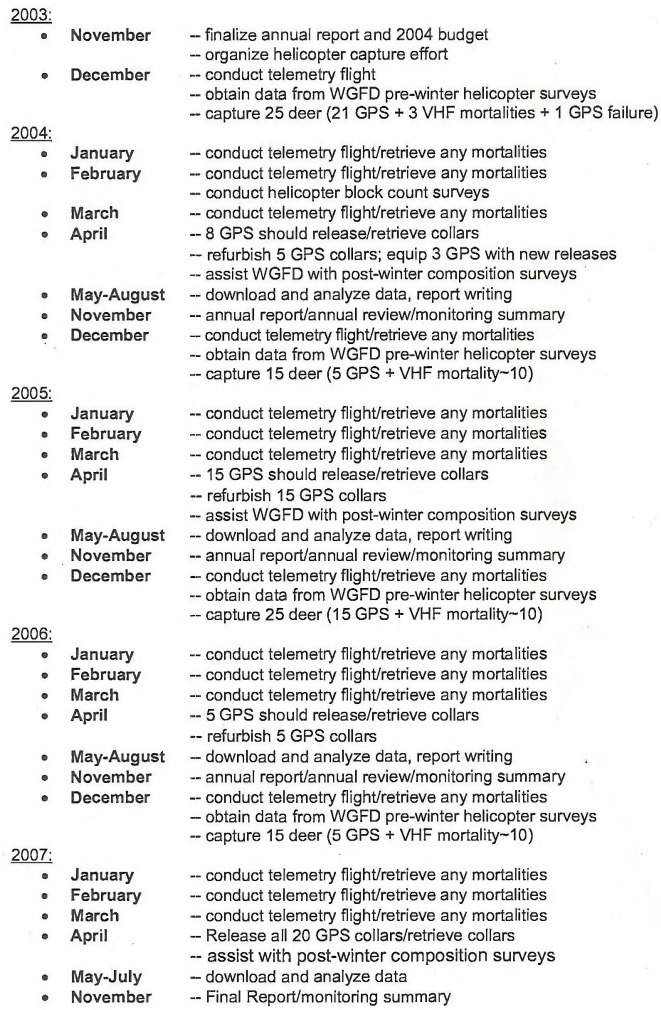




\subsection{LITERATURE CITED}

Anderson, S.H. 1999. Managing our wildlife resources. Prentice Hall, Upper Saddle River, New Jersey. 540 pp.

Bureau of Land Management. 2000. Record of Decision: Environmental impact statement for the Pinedale Anticline natural gas field exploration and development project prepared for Pinedale Field Office, Wyoming.

2002. Oil and Gas Activity on Public Lands in the United States and Wyoming. USDI-BLM, Wyoming State Office. $97 \mathrm{pp}$.

Czaplewski, R.L., D.M. Crowe, and L.L. McDonald. 1983. Sample sizes and confidence intervals for wildlife population ratios. Wildlife Society Bulletin 11:121-128.

D'Eon, R.G.; R. Serrouya, G. Smith, and C.O. Kochanny. 2002. GPS radiotelemetry error and bias in mountainous terrain. Wildlife Society Bulletin 30:430-439.

Di Orio, A. P., R. Callas, and R.J. Schaefer. 2003. Performance of two GPS telemetry collars under different habitat conditions. Wildlife Society Bulletin 31:372-379.

Freddy, D.J. 2001. Project summary report: Deer aerial survey population estimation for Rangely Deer Data Analysis Unit (D-6), Game Management Unit 10. Colorado Division of Wildlife, Fort Collins, CO.

Green, R.H. 1979. Sampling design and statistical methods for environmental biologists. Wiley, New York.

Kaplan, E.L. and P. Meier. 1985. Nonparametric estimation from incomplete observations. Journal of American Statistical Association 53:457-581.

Mackie, R.J., D.F. Pac, K.L. Hamlin, and G.L. Dusek. 1998. Ecology and management of mule deer and white-tailed deer in Montana. Montana Fish Wildlife and Parks. 180 pp.

Manly, B. F. J. 2001. Statistics for environmental science and management. Chapman \& Hall, Boca Raton, Florida. $326 \mathrm{pp}$.

., L. McDonald, D. Thomas, T. McDonald, and W. Erickson. 2002. Resource Selection by Animals: Statistical Design and Analysis for Field Studies, Second Edition. Kluwer Academic Publishers, Boston. $221 \mathrm{pp}$.

McDonald, T.L., W.P. Erickson, and L.L. McDonald. 2000. Analysis of count data from before-after control-impact studies. Journal of Agricultural, Biological, and Environmental Statistics 5:262279.

Moen, R., J. Pastor, Y. Cohen, and C. Schwartz. 1996. Effects of moose movement and habitat use on GPS collar performance. Journal of Wildlife Management 60:659-668.

Morrison, M.L., W.M. Block, M.D. Strickland, and W.L. Kendall. 2001. Wildlife Study Design. Springer, New York. 210 pp. 
Rempel, R.S., A.R. Rodgers, and K.F. Abraham. 1995. Performance of a GPS animal location system under boreal forest canopy. Journal of Wildlife Management 59:543-551.

Samuel, M.D., E.O. Garton, M.W. Schlegel, and R.G. Carson. 1987. Visibility bias during aerial surveys of elk in northcentral Idaho. Journal of Wildlife Management 51:622-630.

., R.K. Steinhorst, E.O. Garton, and J.W. Unsworth. 1992. Estimation of wildlife population ratios incorporating survey design and visibility bias. Journal of Wildlife Management 56:718725.

SAS Institute, Inc. 2000. SAS/STAT Users Guide, Cary, N.C.: SAS Institute.

Sawyer, H. and F. Lindzey. 2001. The Sublette mule deer study. Wyoming Cooperative Fish and Wildlife Research Unit, Laramie, WY. 54 pp.

., D. Strickland, and L. McDonald. 2002. Summary of 2002 project results and scope of longterm monitoring plan to assess potential impacts of energy development on mule deer in the Pinedale Anticline Project Area. Western Ecosystems Technology, Inc. Cheyenne, WY. 37pp.

Thomas, T. and L. Irby. 1990. Habitat use and movement patterns by migrating mule deer in southeastern Idaho. Northwest Science 64:19-27.

Thompson, W.L., G.C. White, and C. Gowan. 1998. Monitoring Vertebrate Populations. Academic Press, San Diego, California, USA. 365 pp.

TRC Mariah Associates. 2003. Mule Deer Winter Use on Areas Proximal to Section 16, T32N, R109W, and Sections 32 and 33, T33N, R109W, Before, During, and After Years with Oil and Gas Development Activity. TRC Mariah Associates Inc. Laramie, WY. 18pp.

Unsworth, J.W., D.F. Pac, G.C. White, R.M. Bartmann. 1999. Mule deer survival in Colorado, Idaho, and Montana. Journal of Wildlife Management 63(1):315-326.

Wells, D.E., editor. 1986. Guide to GPS positioning. Canadian GPS Association, Fredericton, New Brunswick, Canada.

White, G.C., A.F. Reeve, F.G. Lindzey, and K.P. Burnham. 1996. Estimation of mule deer winter mortality from age ratios. Journal of Wildlife Management 60:37-44.

Wyoming Game and Fish Department. 2000. Annual Big Game Herd Unit Report. Jackson/Pinedale Region. Wyoming Game and Fish Department, Cheyenne, WY. . 2001. Annual Big Game Herd Unit Report. Jackson/Pinedale Region. Wyoming Game and Fish Department, Cheyenne, WY. 2002. Annual Big Game Herd Unit Report. Jackson/Pinedale Region. Wyoming Game and Fish Department, Cheyenne, WY. 
$U=$ Total number of quadrats

$u=$ Number of quadrats sampled

$A=$ area contained in the sampling frame

$\bar{N}=\frac{\sum_{i=1}^{u} N_{i}}{u}=$ Mean number of deer per quadrat

$\hat{D}=\frac{\hat{N}}{A}=$ Density estimate

$\hat{N}=U \times \bar{N}=$ Abundance Estimate

$\hat{S}_{N_{i}}=\frac{\sum_{i=1}^{u}\left(N_{i}-\bar{N}\right)^{2}}{u-1}=$ Estimated variance of the mean

$C V(\hat{N})=\frac{S E(\hat{N})}{\hat{N}}=$ Coefficient of variation for abundance estimate

$\operatorname{Var} r(\hat{N})=U^{2}\left[\left(1-\frac{u}{U}\right) \frac{\hat{S}^{2}{ }_{N_{i}}}{u}\right]=$ Estimated variance for abundance estimate

$\operatorname{Vâr}(\hat{D})=\frac{\operatorname{Vâr}(\hat{N})}{A^{2}}=$ Estimated variance for density estimate

$S E(\hat{D})=\sqrt{\operatorname{Var}(\hat{D})}=$ Standard error for density estimate

$S E(\hat{N})=\sqrt{\operatorname{Vâ}(\hat{N})}=$ Standard error for abundance estimate 
SPECIES: Mule Deer

DAU NAME: Sublette (104)

HUNT AREAS: $130,138-142,146,150-156,162$

TITLE: $\quad 2002$ Sublette Mule Deer JCR

\section{BACKGROUND}

The Sublette Mule Deer Herd Unit contains 2,682 miles of habitat throughout Teton, Sublette, Lincoln and Sweetwater Counties. This deer herd contains 15 hunt areas $(130,138-142,146,150-156,162)$ and is managed under special status which mandates postseason buck:100 doe ratios range between 30 to $45: 100$. The postseason population objective is 32,000 deer. High elevation summer habitat $(7,500-$ 10,000 feet) and transition ranges (7,000-8,000 feet) encompass six mountain zones (Gros Ventre Range, Hoback Basin, Salt River Range, Snake River Range, Wind River Range, and Wyoming Range). Winter ranges are located on lower elevation ( $\leq 7,500$ feet) sagebrush communities along the Wyoming Range, Wind River Range and Mesa Complex.

During the decade of the 1990s, this deer herd experienced two winters that resulted in above normal fawn mortality. In 1992-93, 52\% of the juvenile cohort suffered significant winter losses. In 1996-97, $8 \%$ of the juvenile production was lost over-winter. Thus, management in the 1990 s was conservative, antlerless harvest was not utilized and buck harvest was reduced to allow this population to increase toward objective. Over the past three hunting seasons (2000-2002), antlerless harvest was increased as deer numbers approached the postseason objective of 32,000 .

\section{MANAGEMENT EVALUATION}

The 2002 postseason population estimate is approximately 32,900 deer. This represents a $12 \%$ decline from the 2001 postseason estimate of 37,400 deer. The recent population decline is attributed to reduced fawn production/survival and increased antlerless harvest. Based on projected population parameters and 2003 harvest estimates, the 2003 posthunt population should total approximately 33,000 deer.

\section{Classification Data}

A total of 8,402 deer were classified during the 2002 postseason surveys (Table 1). Total number of deer classified was down from 2001 when 11,227 deer were recorded (Appendix A). However, total flight time for this herd was reduced by 3.5 hours resulting in less winter range surveyed in 2002 . Mild winter weather also contributed to fewer deer counted as many deer were distributed throughout fall transition ranges during the December survey. Deer were encountered on all traditional winter ranges including; Ryegrass, Soapholes, Cora Butte, The Mesa, Fremont Butte, Elk Mountain, and the foothill region from Fremont Ridge to Big Sandy River.

Overall, encounter rates (\# of deer/hour) were down slightly from $2001(n=604)$ totaling 564 deer per hour (Table 2). Fewer deer were encountered in Hunt Areas 130, 138, and 139 while rates increased substantially in Hunt Areas 140 and 142. These data support the observation that mild weather conditions had not forced large concentrations of deer onto core winter ranges and were widely dispersed throughout the Ryegrass, Cora Butte and Fremont Ridge complexes. 
Table 1. Sublette Mule Deer Herd postseason classifications, December 2002.

\begin{tabular}{|c|c|c|c|c|c|c|c|c|c|}
\hline \multirow{2}{*}{$\frac{\text { Hunt }}{\text { Area }}$} & \multicolumn{3}{|c|}{$\begin{array}{l}\text { Adult Males } \\
\text { Antler Class* }\end{array}$} & \multirow[b]{2}{*}{$\frac{\text { Yrlng }}{\text { Bucks }}$} & \multirow[b]{2}{*}{$\frac{\text { Total }}{\text { Bucks }}$} & \multirow[b]{2}{*}{ Does } & \multirow[b]{2}{*}{ Fawns } & \multirow[b]{2}{*}{ Unc. } & \multirow[b]{2}{*}{ Total } \\
\hline & I & II & III & & & & & & \\
\hline 130 & 107 & 71 & 45 & 142 & 365 & 1514 & 950 & - & 2829 \\
\hline 138 & 119 & 50 & 19 & 124 & 312 & 963 & 652 & - & 1927 \\
\hline 139 & 106 & 44 & 12 & 131 & 293 & 985 & 624 & - & 1902 \\
\hline 140 & 24 & 20 & 7 & 27 & 78 & 231. & 140 & - & 449 \\
\hline 142 & 57 & 32 & 8 & 66 & 163 & 525 & 361 & - & 1049 \\
\hline 150 & 9 & 15 & 4 & 7 & 35 & 100 & 49 & - & 184 \\
\hline 151 & 0 & 1 & 0 & 1 & 2 & 10 & 9 & - & 21 \\
\hline 152 & 2 & 1 & 0 & 1 & 4 & 14 & 10 & 3 & 31 \\
\hline 155 & 0 & 0 & 0 & 0 & 0 & 0 & 0 & - & 0 \\
\hline$\underline{156}$ & $\underline{0}$ & 4 & $\underline{0}$ & $\underline{0}$ & $\underline{4}$ & $\underline{3}$ & $\underline{3}$ & $=$ & 10 \\
\hline Total & 424 & 238 & 95 & 499 & 1256 & 4345 & 2798 & 3 & 8402 \\
\hline
\end{tabular}

* Class I = less than 20 inches, Class II = 20 - 25 inches, Class III = greater than 25 inches

Total Bucks: 100 Does $=29: 100$

Yring Bucks: 100 Does $=11: 100$

Adult Bucks: 100 Does $=17: 100$

Fawns: 100 Does $=64: 100$

Observed ratios for the 2002 postseason survey were 29 bucks:100 does:64 fawns. A total of 17 adult bucks: 100 does and 11 yearling bucks: 100 does were recorded. Total buck ratios declined below $30: 100$ does for the first time since 1985. Poor fawn production in 2001 resulted in poor yearling buck recruitment (11 ylg:100 does) in 2002 and contributed significantly to a lower overall buck ratio. Yearling buck ratios were noticeably low in 2002 (Appendix B, Figure 1) at 11:100 does. This is the lowest yearling ratio recorded since 1997 following the $1996-97$ winter when over $50 \%$ of the fawn crop died on winter ranges. Yearling buck recruitment is not expected to improve for posthunt 2003 as the 2002 fawn crop was even lower than 2001 at 64 fawns:100 does and the measured fawn loss for the 2002-03 winter was $34 \%$.

Table 2. Encounter rates (deer/hour) for postseason surveys, $1993-2002$.

\begin{tabular}{|c|c|c|c|c|c|c|c|c|c|c|}
\hline Hunt Area & 1993 & 1994 & 1995 & 1996 & 1997 & 1998 & 1999 & 2000 & 2001 & 2002 \\
\hline
\end{tabular}

\begin{tabular}{|l|l|l|l|l|l|l|l|l|l|l|}
\hline 130 & 356 & 653 & 595 & 984 & 479 & 565 & 776 & 701 & 879 & 754 \\
\hline 138 & 168 & 432 & 347 & 335 & 402 & 465 & 565 & 474 & 604 & 448 \\
\hline 139 & 409 & 562 & 513 & 544 & 455 & 653 & 714 & 559 & 630 & 594 \\
\hline 140 & 304 & 166 & 158 & 140 & 296 & 329 & 591 & 304 & 274 & 374 \\
\hline 142 & 545 & 414 & 307 & 660 & 363 & 664 & 543 & 697 & 277 & 524 \\
\hline
\end{tabular}

Total

\begin{tabular}{l|l}
339 & 498
\end{tabular}

\begin{tabular}{|l|l|l|}
\hline 417 & 554 & 427 \\
\hline
\end{tabular}

\begin{tabular}{|l|l|}
\hline 571 & 625 \\
\hline
\end{tabular}

\begin{tabular}{|l|l|l|}
\hline 578 & 604 & 564 \\
\hline
\end{tabular}


Fawn:100 doe ratios dropped to $64: 100$ in 2002. This was the second consecutive year of declining fawn production (Figure 2). While recent winter weather has been mild, poor shrub conditions due to a continued drought has dramatically impacted fawn production and survival. The long-term average (1986-2001) fawn:100 doe ratio for this herd unit stands at 73:100. Continued declines in fawn production will make it difficult to meet overall management goals for postseason buck ratios (3045:100) without reducing buck harvest.

Figure 1. Yearling Buck:100 Doe ratios, 1991-2002, Sublette Mule Deer Herd Unit.

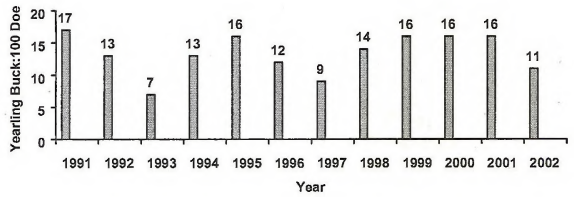

Classification of all adult males was categorized in three antler width classes (Table 3 ). These data help assess the long-term effects of management strategies on males within this herd unit. The proportion of yearlings in the 2002 sample dropped $5 \%$ reflective of a poor fawn crop in 2001 . The Class I category increased from $25 \%$ in 2001 to $34 \%$ in 2002 . This reflects above average fawn production in $2000(82: 100)$ and good over-winter survival (26\% fawn mortality in 2000$)$. Bucks in the Class II category for 2002 declined, particularly when compared to the other adult buck categories (Table 3 ). This class category is typically represented by 3 and 4 year old animals based on past age specific data (see $2001 \mathrm{JCR}$, page 35). Fawn productivity and over-winter survival was above average 1998 and 1999 contributing several robust age classes for this herd unit. The 2002 hunting season was extended by six days (from October 14 to October 20) to allow for increased harvest. Given hunter preference for mature, branch antlered deer, it is likely these two age classes contributed significantly to the 2002 harvest thus the drop in the proportion of this class category in the postseason survey. The percentage of class category III bucks declined only slightly in 2002 indicating that 5 year and older age class bucks are being recruited into this category at a low, but constant rate in the absence of significant winter mortality.

Figure 2. Fawn:100 Doe ratios, 1991-2002, Sublette Mule Deer Herd Unit.

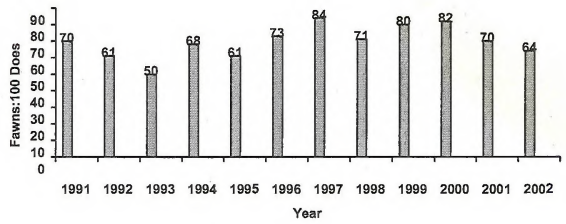




\section{Change-in-Ratio}

Regional wildlife managers annually conduct fall and early spring herd composition surveys to assess winter fawn losses. Winter ranges are surveyed in December and April to document the proportion of fawns:100 adults by individual hunt area (Table 4). By documenting the change in fawn:100 adult ratios from December to April, a minimum estimate of fawn loss is calculated (Table 5).

Analysis of change-in-ratio data has proven effective in identifying winters of significant fawn mortality. However, significant shifts in deer distribution can occur between the December and April surveys resulting in movements between hunt areas. Due to the variability of these movements, the most accurate depiction of these data occurs when the information is pooled for the biological year and compared to previous years (Figure 3 ).

Table 3. Postseason classification of males into antler width classes, Sublette Mule Deer Herd Unit, 2002.

Adult Male Antler Class

\begin{tabular}{|c|c|c|c|c|c|}
\hline & Class I & Class II & Class III & Total Males & Yearlings \\
\hline Sample Size & 424 & 238 & 95 & 1256 & 499 \\
\hline $\begin{array}{c}\% \text { of Total } \\
\text { Males }\end{array}$ & $34 \%$ & $19 \%$ & $8 \%$ & -- & $40 \%$ \\
\hline $\begin{array}{c}\% \text { of Adult } \\
\text { Males }\end{array}$ & $56 \%$ & $31 \%$ & $13 \%$ & -- & - \\
\hline
\end{tabular}

Class $1-<20$ inches, Class $11-20-25$ inches, Class $111->25$ inches

The estimated 2002-03 fawn loss was 34\% (Table 5, Fig. 3). Winter losses from 2002-03 were very similar to the previous winter (2001-2002) when $33 \%$ of the annual fawn production was lost. Overwinter fawn mortality has gradually increased since 1999-00 and can be attributed in part, to continued summer drought effects on winter browse productivity. Data derived from the change-inratio estimates are used to adjust postseason mortality estimates for the POP-II model. These data have been invaluable in refining model parameters. In addition, yearling buck:100 doe ratios provide an additional "quality" check of model parameters. However, this data lags one year behind and is not useful in predicting ongoing mortality events. Change-in-ratio information does provide early detection of significant winter losses that can be utilized for hunt season planning, before the following year's yearling buck: 100 doe classifications further refine actual over-winter losses.

Table 4. Post winter classification April 2003, Sublette Mule Deer Herd Unit

\begin{tabular}{|c|c|c|c|c|}
\hline Hunt Area & Fawns & Adults & Total & Fawns :100 Adults \\
\hline & & & & \\
\hline 130 & 30 & 73 & 103 & 41 \\
\hline 138 & 42 & 121 & 163 & 35 \\
\hline 139 & 182 & 510 & 692 & 36 \\
\hline 140 & 322 & 1045 & 1367 & 31 \\
\hline 142 & 148 & 444 & 592 & 33 \\
\hline Total & 724 & 2193 & 2917 & 33 \\
\hline
\end{tabular}

\section{Mule Deer Winter Mortality Surveys}

In addition to quantifying fawn losses via change-in-ratio surveys, winter range mortality surveys were 
also conducted in May 2003 to document the sex and age composition of over-winter mortalities. As expected, fewer adult carcasses were reported in 2003 due to the relatively mild winter conditions. Similar to past mild winters, fawns comprised the majority of all carcasses encountered totaling $50 \%$ of all recorded mortalities (Table 6). Although the 2003 sample was small $(n=103)$, these data provide a useful index to the sex/age composition of winter losses.

Table 5. Fawn:100 Adult ratios obtained from post-season (December) classification surveys and post- winter (April) classification surveys for the 2002-2003 winter, Sublette Mule Deer Herd Unit.

\begin{tabular}{|c|c|c|c|}
\hline $\begin{array}{c}\text { Hunt } \\
\text { Area }\end{array}$ & Dec-02 & Apr-03 & \% Change \\
\hline & & & \\
\hline 130 & 51 & 41 & $-20 \%$ \\
\hline 138 & 51 & 35 & $-31 \%$ \\
\hline 139 & 49 & 36 & $-26 \%$ \\
\hline 140 & 45 & 31 & $-31 \%$ \\
\hline 142 & 52 & 33 & $-37 \%$ \\
\hline Total & 50 & 33 & $-34 \%$ \\
\hline
\end{tabular}

Figure 3. Percent change-in-ratio (fawn loss) for the winters of 1992-1993, through 2002-2003 in the Sublette Mule Deer Herd Unit.

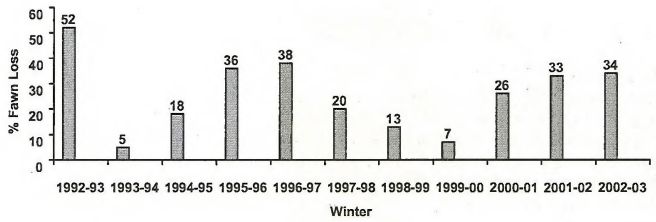

\section{Weather Data}

Weather data for reporting stations located throughout the Sublette herd unit are listed in Appendix C. There is a high degree of variability from the various reporting stations and no one station represents conditions for the entire herd unit. Regional managers continue to use on-the-ground surveys to assess over-winter mortality rather than projecting losses based on weather parameters from reporting stations.

\section{Modeling}

The POP-II model, version 1.2.5 was updated using 2002 harvest data, postseason sex/age classification information, and winter mortality data. Model parameters were changed this year to reflect statewide standardized fecundity rates, pre- and postseason MSI levels, adult mortality rates, and pre- and postseason juvenile mortality rates. These changes were mandated in a Wildlife Division Administration memorandum dated March 26, 2003.

In general, this model tracks observed data very well. Postseason yearling male and adult male:100 
doe ratios align closely with field data. The postseason 2002 population estimate was 32,900 , down $12 \%$ from the 2001 estimate of 37,400 . The objective for this herd unit is 32,000 deer.

Table 6. 2001-2002 Winter mortality survey results, Sublette Mule Deer Herd Unit.

\begin{tabular}{|c|c|c|c|c|c|}
\hline Location & Fawns & $\begin{array}{l}\text { Adult } \\
\text { Males }\end{array}$ & \begin{tabular}{c|} 
Adult \\
Females
\end{tabular} & $\begin{array}{c}\text { Unknown } \\
\text { Adults }\end{array}$ & Total \\
\hline & & & & & \\
\hline Mesa East & 8 & 3 & 4 & 0 & 15 \\
\hline \begin{tabular}{|l} 
Elk \\
Mountain
\end{tabular} & 34 & 7 & 11 & 16 & 68 \\
\hline $\begin{array}{l}\text { Fremont } \\
\text { Butte }\end{array}$ & 8 & 2 & 3 & 1 & 14 \\
\hline Ryegrass & 1 & 0 & 1 & 0 & 2 \\
\hline $\begin{array}{l}\text { Scab } \\
\text { Creek }\end{array}$ & 0 & 0 & 4 & 0 & 4 \\
\hline Total & 51 & 12 & 23 & 17 & 103 \\
\hline $\begin{array}{l}\% \text { of Total } \\
\text { Mortalities }\end{array}$ & $50 \%$ & $12 \%$ & $22 \%$ & $17 \%$ & \\
\hline
\end{tabular}

\section{Harvest Statistics}

The 2002 harvest survey reported 8,270 hunters harvested 3,607 deer in this herd unit. This represented an $11 \%$ increase in deer hunters and $12 \%$ increase in deer harvested as compared to 2001. Hunter numbers were up $18 \%$ in 2002 when compared to the 5 -year average. Similarly, deer harvest increased 52\% over the 5-year average reflecting increased hunter opportunities in 2002. Hunter success remained steady in 2002 totaling $44 \%$. Success in 2001 was $43 \%$ and the 2000 hunting season totaled $46 \%$. Days per animal harvested totaled 13.9 in 2002, virtually unchanged from 2001 when 13.4 days were required to harvest a deer. Total recreation days generated from the 2002 hunting season was 50,400, a 17\% increase over recreation days for 2001 .

The 2002 hunting season was extended by six days for hunt areas $142,153,154$. In addition, general license hunters could hunt "any deer" for the entire season in hunt areas 142, 146, 151-156 (September 15 to October 20) which was more liberal than the 2001 hunting season. Finally, an additional 200 nonresident licenses were added to the Region $\mathrm{H}$ quota, totaling 1,800 hunters.

Liberalizing the 2002 hunting season resulted in increased resident hunter participation, up 11\% $(n=615)$ from 2001 levels. Residents took advantage of the longer "any deer" season by harvesting 769 does and 64 fawns. The 2002 resident antlerless harvest increased 100\% (n=417) over 2001. Surprisingly, resident buck harvest declined slightly from 2001 levels. A total of 1,867 males were reported killed in 2002, a decline of $3 \%(n=57)$ despite the longer, liberal season.

Increasing the nonresident quota for Region $\mathrm{H}$ by 200 licenses did not increase total buck harvest for this herd unit. Hunter success declined from $55 \%$ in 2001 to $50 \%$ in 2002 with total buck harvest declining from 863 in 2001 to 856 bucks reported killed in 2002. Nonresident antlerless harvest increased slightly with 50 deer reported in 2002 compared to 19 in 2001 . Nonresidents accounted for $31 \%$ of the total buck harvest and only $6 \%$ of the total antlerless kill.

From 1994 to 2001 , age of field checked buck deer was correlated with antler width measurements. This data has been useful in characterizing antler size with age structure of the harvest and deer population in general. Due to budget constraints this year, no age specific (cementum annuli) harvest information was available. A total of 804 deer were field checked during the 2002 hunting season (589 
bucks and 215 does and fawns). The 2002 field checks represented $22 \%$ of the total reported harvest. In $2001,21 \%$ of the total reported harvest was field checked. The long-term average (1992-2000) for field checks compared to reported harvest for this herd unit stands at $15 \%$.

Antler measurements were recorded for harvested adult bucks in 2002 (Table 7). A very small sample ( $n=57$ ) was collected in 2002 and should be interpreted cautiously as the proportion of Class I, II, III bucks in the harvest (Table 7) does not reflect the proportion of the same antler classes observed during the December postseason classification survey (Appendix B). Class II bucks (20"-25") accounted for the majority of the field checked deer $(60 \%)$ which is significantly higher than the previous two years (Table 7). Postseason 2002 surveys estimated $31 \%$ of the adult males classified were in the Class II category (Appendix B) which typically represents the 3 and 4 year old age classes. As discussed earlier, fawn productivity and survival was above average in 1998 and 1999 which represent Class II bucks (3-4 yr. olds) in this population.

Table 7. Antler widths from adult bucks harvested in the Sublette Herd, 2000-2002.

\begin{tabular}{|l|c|c|c|}
\hline $\begin{array}{c}\text { Adult Male } \\
\text { Antler Width }\end{array}$ & 2000 & 2001 & 2002 \\
\hline Class I < 20" & $60(28 \%)$ & $72(43 \%)$ & $15(26 \%)$ \\
\hline Class II 20"-25" & $82(38 \%)$ & $56(34 \%)$ & $34(60 \%)$ \\
\hline Class III > 25" & $72(34 \%)$ & $39(23 \%)$ & $8(14 \%)$ \\
\hline \multicolumn{4}{r}{ Total } \\
\hline
\end{tabular}

\section{Management Summary}

In summary, this population was essentially at, or slightly below objective in 1992 following several years of actively reducing deer numbers. This herd "hit bottom" following the 1992-93 winter, resulting in a dramatically reduced postseason 1993 population. Due to conservative "buck only" seasons and no antlerless harvest, the population was recovering as rapidly as possible through 1994 and 1995. Poor fawn crops allowed for only moderate growth, however. Winter mortality in the 1995-96 winter stalled the growth of this population and losses sustained during the 1996-97 winter caused a further setback. The recovery resumed with the gradual growth experienced since the 1996-97 winter. Relatively high fawn production in 1999 and 2000 facilitated rapid population growth. Even with mild winter conditions, declining fawn production in 2001 and 2002 coupled with antlerless harvest has slowed population growth.

Hunting seasons in the Pinedale area have closed prior to the second weekend in October since 1994, with Jackson areas running somewhat longer. The 1999 season was the first time since 1993 that general license seasons ran through the second weekend in October in the Pinedale areas. For 2000 , it was recommended that the season run through October 14 and general license "any" deer hunting for select hunt areas be offered. In 2002, the general license "any" deer season was lengthened to October 20. The 2003 season proposal will restrict "any" deer hunting to the early portion of the season (September 15-30). Due to the fact that seasons in the late 1980s and early 1990s likely impacted resident deer along the Pinedale Front, "any" deer hunting will be closely monitored for Hunt Areas 130, 138, 139, and 140 along the Wind River Front. Antlerless harvest for these hunt areas totaled 311 for the 2002 season, $35 \%$ of the entire herd unit.

This population has grown to a point where it has reached, and exceeded the population objective. Fawn losses sustained during the 2002-2003 winter, along with 2002 antlerless harvest, slowed population growth. Because this herd is slightly over objective, buck ratios are good, and public acceptance of deer numbers seem favorable, an "any" deer season is again proposed (September 
15-30) and antlered deer hunting will run October 1-14. For similar reasons, the nonresident quota will remain at 1,800 licenses.

POP-II model projections for years 2003 and beyond illustrate that it is unrealistic to maintain the level of antlered deer harvest as reported from 2000 to 2002 and maintain a buck:100 doe ratio of 30 or greater. Recent mild winter weather has reduced winter mortality. However, it appears drought conditions are impacting winter ranges as fawn production has declined $22 \%$ from $82: 100$ does in 2000 to $64: 100$ does in 2002 . The 2003 seasons are projected to harvest a total of 2915 deer ( 2500 bucks, 415 doe/fawn) and stabilize the population around 33,000 deer.

\section{Management Recommendations}

1. Continue helicopter surveys to gather post season classification information. We are beginning to compile an extremely good, continuous set of classification data. The distribution, encounter rate, and antler width class data, which have been collected the last 5 years, have been very valuable, and the consistency of this information should remain a priority.

2. Eventually incorporate information gained from the Sublette Deer Study into management of this deer herd. Initial results from this study have identified the need to extensively revise the seasonal range maps for this herd unit. Crucial winter ranges, particularly need to be expanded dramatically. The importance of previously known critical migration bottlenecks has been illustrated. Any proposed land use changes in the vicinity of the Cora $Y$ and the outlet of Fremont Lake should be scrutinized. Initiate an effort to protect and preserve open space in these bottlenecks using what means available to the Department.

3. Continue to perform spring deer classifications in order to obtain change-in-ratio information with which to assess winter mortality. An added goal should be to compare our estimates of winter losses with those obtained from the model developed by White et al. (1996) - White, G.C., A.F. Reeve, F.G. Lindzey, and K.P. Burnham. 1996. Estimation of Mule Deer Winter Mortality from Age Ratios. J. Wildl. Manage. 60(1):37-44.

4. Continue deer mortality surveys during April and May to collect carcass composition data with which to run the White et al. (1996) model. In addition, these surveys provide a comparison to past years, if the same winter ranges are surveyed each year.

5. Pursue outside funding in order to analyze teeth for assessment of age structure impacts of management strategies.

6. Continue to monitor impending natural gas development on deer winter ranges within this herd unit and seek to protect crucial habitat on public lands or mitigate its loss, if possible. 
-

-

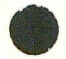

